\title{
CD38 affects the biological behavior and energy metabolism of nasopharyngeal carcinoma cells
}

\author{
YANSHAN GE ${ }^{1-4^{*}}$, YUEHUA LONG ${ }^{1-3^{*}}$, SONGSHU XIAO ${ }^{5}$, LIN LIANG ${ }^{1-4}$, ZHENGXI HE $^{1-4}$, \\ CHUNXUE YUE ${ }^{1-4}, \mathrm{XIONG}^{\mathrm{W}} \mathrm{II}^{1-4}$ and YANHONG ZHOU ${ }^{1-4}$ \\ ${ }^{1}$ Department of Oncology, Hunan Provincial Tumor Hospital, Xiangya School of Medicine, Central South University, \\ Changsha, Hunan 410006; ${ }^{2}$ Basic School of Medicine; ${ }^{3}$ Cancer Research Institute, Central South University, \\ Changsha, Hunan 410008; ${ }^{4}$ Key Laboratory of Carcinogenesis of Ministry of Health and Key Laboratory of \\ Carcinogenesis and Cancer Invasion of Ministry of Education, Cancer Research Institute; \\ ${ }^{5}$ Department of Gynecology and Obstetrics, The Third Xiangya Hospital, \\ Central South University, Changsha, Hunan 410078, P.R. China
}

Received July 25, 2018; Accepted October 12, 2018

DOI: 10.3892/ijo.2018.4651

\begin{abstract}
Nasopharyngeal carcinoma (NPC) is the most common malignant tumor type in Southern China and South-East Asia. Cluster of differentiation (CD)38 is highly expressed in the human immune system and participates in the activation of T, natural killer and plasma cells mediated by CD2 and CD3 through synergistic action. CD38 is a type II transmembrane glycoprotein, which was observed to mediate diverse activities, including signal transduction, cell adhesion and cyclic ADP-ribose synthesis. However, the significance of CD38 in NPC biological behavior and cellular energy metabolism has not been examined. In order to elucidate the effect of CD38 on the biological behavior of NPC cells, stable CD38-overexpressed NPC cell lines were established. It was demonstrated that CD38 promoted NPC cell proliferation with Cell Counting Kit- 8 and colony formation assays. It was also indicated that CD38 inhibited cell senescence, and promoted cell metastasis. Furthermore, it was determined that CD38 promoted the conversion of cells to the $\mathrm{S}$ phase and decreased the content of reactive oxygen species and $\mathrm{Ca}^{2+}$. Additionally, cell metabolism assays demonstrated
\end{abstract}

Correspondence to: Professor Yanhong Zhou, Cancer Research Institute, Central South University, 110 Xiangya Road, Changsha, Hunan 410078, P.R. China

E-mail: zhouyanhong@csu.edu.cn

Abbreviations: NPC, nasopharyngeal carcinoma; HL, lactic acid; cAMP, cyclic adenosine monophosphate; GEO, Gene Expression Omnibus; KEGG, Kyoto Encyclopedia of Genes and Genomes; PPI, protein-protein interaction; TP53, tumor protein p53; CDK cyclin-dependent kinase

*Contributed equally

Key words: nasopharyngeal carcinoma, cluster of differentiation 38, cell proliferation, cell metabolism that CD38 increased the concentration of ATP, lactic acid, cyclic adenosine monophosphate and human ADP/acrp30 concentration in NPC cells. To investigate the possible mechanism, bioinformatics analysis and mass spectrometry technology was used to determine the most notably changing molecule and signaling pathways, and it was determined and verified that $\mathrm{CD} 38$ regulated the metabolic-associated signaling pathways associated with tumor protein 53 , hypoxia inducible factor- $1 \alpha$ and sirtuin 1 . The present results indicated that CD38 may serve a carcinogenic role in NPC by regulating metabolic-associated signaling pathways.

\section{Introduction}

Nasopharyngeal carcinoma (NPC) refers to malignant tumors that occur on the top and sidewall of the nasopharyngeal cavity $(1,2)$. NPC is one of the most prevalent malignant tumor types in China since 2002-2014 $(3,4)$. Risk factors for NPC include Epstein-Barr virus infection (5), genetic factors, intake of salted food and cigarette smoking (6-9). Female patients accounted for $30 \%$ of cases from 1983-2008 in Hong Kong, indicating that NPC is more common in males $(10,11)$. Currently, radiation therapy is the preferred method used in the treatment of NPC, due to the majority of the NPC cases being poorly differentiated carcinomas (12). The treatment methods of NPC also include surgical treatment and chemotherapy, to improve patient survival rate (13-16).

Nutritional competition among cells can affect the growth, survival and functions. Different cells have different nutrient intake conditions and energy metabolism phenotypes. Therefore, the state of cells is associated with energy metabolism (17). Cluster of differentiation (CD)38 is located on chromosome 4 and was originally observed as a lymphocyte surface antigen. The molecular weight is $45 \mathrm{kDa}$ (18). A number of studies demonstrated that CD38 was a transmembrane protein with receptors, extracellular enzymes and other functions (19-21). CD38 is primarily considered as a Type II membrane protein with a small N-terminal tail 
protruding into the cell and a catalytically active C-terminus located extracellularly (22). CD38 is not only expressed in $\mathrm{T}$ lymphocytes, but also expressed in other immune cells, including plasma cells, natural killer cells, monocytes and dendritic cells (23). CD38 is an important target in the treatment of multiple myeloma (24). In particular, the CD38 targeted therapies exhibit single-agent activity in early-phase clinical trials (25-27).

Although numerous studies have been conducted on CD38, there is relatively limited research regarding the energy metabolism of CD38 in NPC (28). The purpose of the present study was to determine the expression level of CD38 in NPC, investigate the role of CD38 in the biological behavior and cell metabolism of NPC cells, and to investigate the possible mechanisms.

\section{Materials and methods}

Cell culture and transfection. Human NPC cells, 5-8F cells, were cultured in RPMI-1640 supplemented with $10 \%$ fetal bovine serum (both from Gibco; Thermo Fisher Scientific, Inc., Waltham, MA, USA). Cells were grown at $37^{\circ} \mathrm{C}$ in an atmosphere containing $5 \% \mathrm{CO}_{2}$. Transfection steps were according to the manufacturer's protocols of the lentiviral transfection reagent (Shanghai GenePharma, Co., Ltd., Shanghai, China). Cell transfection was accomplished by using Lipofectamine ${ }^{\circledR} 2000$, according to the manufacturer's instruction (Invitrogen; Thermo Fisher Scientific, Inc.). Firstly, $2 \times 10^{5}$ cells were seeded into each well of a 6 -well plate $24 \mathrm{~h}$ prior to transfection. For each transfection, $2 \mu \mathrm{g}$ pEGFP-N1-CD38 plasmid or pEGFP-N1 vector plasmid (Sangon Biotech Co., Ltd., Shanghai, China) was transfected into 5-8F cells. The plasmids were diluted with $100 \mu \mathrm{l}$ RPMI-1640 and $4 \mu \mathrm{l}$ Lipofectamine 2000 was added into $100 \mu \mathrm{l}$ RPMI-1640. The two solutions were combined, mixed gently and incubated at room temperature for $30 \mathrm{~min}$. Subsequently, the $200 \mu \mathrm{l}$ mixture and $200 \mu 1$ RPMI-1640 were added into each well. The cells were then incubated at $37^{\circ} \mathrm{C}$ for $24 \mathrm{~h}$, followed by replacing the transfection media with RPMI-1640 with $10 \%$ fetal bovine serum. After an additional $48 \mathrm{~h}$ culture, the cells were harvested for the following western-blot experiments. The level of CD38 protein expression was detected by western blot analysis, according to the subsequent protocols, and two replicates were conducted for western blot analysis, to confirm whether the stable cell line was constructed successfully. The primary antibody used was mouse anti-CD38 (ImmunoWay Biotechnology Company,Plano, TX, USA; 1:1,000 dilution; cat. no. YM0122) at $4^{\circ} \mathrm{C}$ overnight. The secondary antibody used was anti-mouse horseradish peroxidase (HRP)-conjugated antibody at $37^{\circ} \mathrm{C}$ for $1 \mathrm{~h}$ (LiankeBio, Hangzhou, China; 1:5,000 dilution; cat. no. GAM007).

Ethical statement. The present study was approved by the Ethics Committee of Hunan Provincial Tumor Hospital (Changsha, China) and conducted in accordance with the Declaration of Helsinki. Prior to the start of the study, all participants provided written informed consent.

Patient samples. A total of 20 NPC specimens and 17 non-tumor NPC epithelial tissues were collected from the Cancer Hospital of Hunan Province, Central South University (Changsha, China). The mean age of the patients was $45 \pm 5.5$ years, including 28 males and 9 females. Biopsy samples were collected from March 17, 2017 to May 17, 2017. The non-cancerous nasopharyngeal tissues were collected from independent patients with chronic inflammation of nasopharyngeal mucosa or polyps.

Immunohistochemistry. For immunohistochemistry, paraffin-embedded specimens were sliced to 4- $\mu \mathrm{m}$ thickness and fixed with $4 \%$ paraformaldehyde for $24 \mathrm{~h}$ at $4^{\circ} \mathrm{C}$. Immunohistochemistry was conducted using the peroxidase anti-peroxidase technique (29) following a microwave antigen retrieval procedure, which included incubating twice in $100 \%$ analytical reagent (AR) ethanol for $5 \mathrm{~min}$, followed by $95 \%$ AR ethanol for $5 \mathrm{~min}, 75 \%$ AR ethanol for $5 \mathrm{~min}, 50 \%$ AR ethanol for $5 \mathrm{~min}$ and then in distilled water for $5 \mathrm{~min}$ at room temperature, and then washed in 1X PBS for 3 min twice at room temperature. Antibody for CD38 was purchased from Immunoway Biotechnology Company. The antibody against CD38 (cat.no. YM0122; Immunoway Biotechnology Company; 1:1,000 dilution) was overlaid on NPC and non-tumor nasopharyngeal epithelial tissues sections and incubated overnight at $4^{\circ} \mathrm{C}$. Anti-mouse HRP-conjugated secondary antibody (dilution 1:5,000; cat. no. GAM007; LiankeBio) was performed at room temperature for $30 \mathrm{~min}$. Color reaction was developed with 3,3'-diaminobenzidine tetrachloride chromogen solution. All slides were counterstained with hematoxylin for $3 \mathrm{~min}$ at room temperature.

Sections were blindly evaluated by two investigators (Department of Pathology, the First Xiangya Hospital, Central South University, Changsha, China) in an effort to provide a consensus on staining patterns by optical microscopy at x40 and x200 magnification (Olympus Corporation, Tokyo, Japan). CD38 staining was assessed according to the methods described by Hara and Okayasu (30) with minor modifications. Each case was rated according to a score that added a scale of intensity of staining to the area of staining. At least 10 high-power fields were selected randomly, and $>1 \times 10^{3}$ cells were counted for each section. The intensity of staining was graded on the following scale: 0 , no staining; $1+$, mild staining; $2+$, moderate staining; and $3+$, intense staining. The area of staining was evaluated as follows: 0 , no staining of cells in any microscopic fields; $1+,<30 \%$ of tissue stained positive; $2+, 30-60 \%$ stained positive; and $3+,>60 \%$ stained positive. The minimum score when calculated was 0 and the maximum was 6 . A combined staining score of $\leq 2$ was considered to be negative staining (low staining), a score of 3-4 was considered to be moderate staining, whereas, a score of 5-6 was considered to be strong staining. An optimal cut-off level was identified as follows: A staining index score of 0-2 was used to define tumors with negative expression and 3-7 indicated positive expression of these two proteins. Agreement between the two evaluators was $95 \%$, and all scoring discrepancies were resolved through discussion between the two evaluators.

Cell proliferation and colony formation assay. The cells were counted and seeded in 96-well plates in a total amount of $100 \mu \mathrm{l}$ RPMI-1640 supplemented with $10 \%$ fetal bovine serum at $1 \times 10^{3}$ cells/well. In accordance with each $100 \mu 1$ 
RPMI-1540 supplemented with $10 \%$ fetal bovine serum by adding $10 \mu \mathrm{l}$ Cell Counting Kit-8 (CCK-8) detection reagent (Shanghai Qibao Xintai Biotechnology Co., Ltd., Shanghai, China; cat. no. C008-3), and incubated at $37^{\circ} \mathrm{C}$ for $1-7$ days. Absorbance was measured at a wavelength of $450 \mathrm{~nm}$ with a microplate reader (Beckman Coulter, Inc., Brea, CA, USA). For the colony formation assay, the cells were digested and then were counted at $\times 100$ magnification with a light microscope. A total of $8 \times 10^{2}$ cells were planted in each well of a 6 -well plate, cultured in a $\mathrm{CO}_{2}$ incubator for 14 days at $37^{\circ} \mathrm{C}$. Cells were fixed with $4 \%$ paraformaldehyde solution for $15 \mathrm{~min}$ at room temperature and stained with $0.1 \%$ crystal violet solution for $20 \mathrm{~min}$ at room temperature, and the number of clones was counted at x40 magnification with a light microscope.

Scratch assay and Transwell. The cells $\left(2.5 \times 10^{5}\right)$ were seeded in 6-well plates and allowed to grow at $37^{\circ} \mathrm{C}$ in an atmosphere containing $5 \% \mathrm{CO}_{2}$ for $24 \mathrm{~h}$. Subsequently, the cells were scratched with a $10 \mu \mathrm{l}$ pipette tip and an image was captured with a light microscope every $12 \mathrm{~h}$ at X100 magnification. The RPMI-1640 was changed every $12 \mathrm{~h}$ at $37^{\circ} \mathrm{C}$ and images were captured in situ until the cell scratch healed. For the Transwell assay, cell counts were performed following digestion of the cells with $0.25 \% 1 \mathrm{X}$ Trypsin EDTA (Gibco; Thermo Fisher Scientific, Inc.). Transwell chambers were used to hold inserts containing cultured cells (Transwell chamber; 8-mm pore size; Costar, High Wycombe, UK). A total of $2 \times 10^{4}$ cells were seeded in each chamber, serum-free RPMI-1640 was added to the upper chamber, and RPMI-1640 culture medium containing $600 \mu \mathrm{l}$ $10 \%$ fetal bovine serum was added to the lower chamber. When cells were visible in 24 plates for $48 \mathrm{~h}$ at $37^{\circ} \mathrm{C}$, the culturing was stopped and the cells were washed 3 times with PBS. Cells were fixed with $4 \%$ paraformaldehyde solution for $10 \mathrm{~min}$ and room temperature and stained with $0.1 \%$ crystal violet solution for $10 \mathrm{~min}$ at room temperature. The cells were imaged with a light microscope at x400 magnification.

$\beta$-galactosidase staining. The detection of cellular senescence was performed using a Senescence-associated $\beta$-Galactosidase Staining kit (Beyotime Institute of Biotechnology, Haimen, China), according to the manufacturer's protocol. In a 6-well plate $\left(1.2 \times 10^{6}\right)$, RPMI-1640 supplemented with $10 \%$ fetal bovine serum was aspirated and the cells were washed once with PBS, and then $1 \mathrm{ml} \beta$-galactosidase staining fixative from a Senescence-associated $\beta$-Galactosidase Staining kit was added for $15 \mathrm{~min}$ at room temperature. Subsequently, the $\beta$-galactosidase staining fixative was aspirated, the cells were washed 3 times with PBS for 3 min each time. Following this, PBS was removed and $1 \mathrm{ml}$ stain solution was added to each well. Finally, the cells were incubated overnight at $37^{\circ} \mathrm{C}$. The staining was observed with a light microscope at x200 magnification, the $\beta$-galactosidase positive cells (blue) were considered senescent.

Flow cytometry of cell cycle and apoptosis. Cells were harvested with $0.5 \%$ trypsin and centrifuged at $1,000 \mathrm{x} \mathrm{g}$ for $5 \mathrm{~min}$ at room temperature. Cell cycle analysis was performed using a cell cycle staining kit (LiankeBio; cat. no. CCS012), cells were fixed in ice-cold $70 \%$ ethanol overnight at $4^{\circ} \mathrm{C}$. Following being washed thrice with cold PBS, cells were suspended in $500 \mu \mathrm{l}$ PBS, and $10 \mu \mathrm{l}$ RNase A was added for $5 \mathrm{~min}$ at room temperature. Subsequently, $10 \mu \mathrm{l}$ propidium iodide (PI; LiankeBio; cat. no. CCS012) was added into the cell resuspension solution, and incubated for $30 \mathrm{~min}$ at $4^{\circ} \mathrm{C}$. The cells were finally washed twice with PBS prior to analysis. As for apoptotic analysis, it was performed using a Hoechst 33342/PI Apoptosis Assay kit (Shanghai BestBio Biotechnology, Shanghai, China), according to the manufacturer's protocols. The samples were washed twice with ice-cold PBS and suspended in $500 \mu l$ staining buffer, and then incubated with $5 \mu \mathrm{l}$ Hoechst 33342 and $5 \mu \mathrm{l} \mathrm{PI}$ in the dark for $20 \mathrm{~min}$ at $4^{\circ} \mathrm{C}$. The cells were finally washed twice with PBS prior to analysis. Analysis was performed on a MoFlo ${ }^{\mathrm{TM}} \mathrm{XDP}$ High-Performance Cell Sorter and the data were analyzed with Summit v5.2 Software (both from Beckman Coulter, Inc.).

Flow cytometry analysis of ROS and $\mathrm{Ca}^{2+}$ concentration. Cells were digested with $0.25 \% 1 \mathrm{X}$ Trypsin EDTA and cultured in RPMI-1640, and $5 \mu 1$ 2,7-dichlorofluorescin diacetate (DCFH-DA) from a ROS kit (Applygen Technologies, Inc., Beijing, China) was added to the test tube. The blank group contained no reagents, whereas $5 \mu \mathrm{l}$ DCFH-DA and $5 \mu \mathrm{l}$ reactive oxygen donor was added to the positive control group and incubated in a constant temperature water bath at $37^{\circ} \mathrm{C}$ for $20 \mathrm{~min}$. Subsequently, cells were washed with $1 \mathrm{X}$ PBS, and then resuspended in $500 \mu 1 \mathrm{1X}$ PBS. ROS was detected with a flow cytometer (Beckman Coulter, Inc.). For the $\mathrm{Ca}^{2+}$ concentration, following digestion of the cells with $0.25 \% 1 \mathrm{X}$ Tryspin EDTA, the cells were resuspended with the culture medium. A total of $1 \mu \mathrm{l}$ Fluorescein- $2 \mathrm{AM} \mathrm{Ca}^{2+}$ fluorescent probe from a $\mathrm{Ca}^{2+}$ analysis kit (S1056; Beyotime Institute of Biotechnology) was added to each tube of the sample to be tested. Subsequently, $1 \mu \mathrm{l}$ dimethyl sulfoxide solution was added into the cell suspension of the control group, and then the tube was inverted and mixed thoroughly every 3-5 min to allow full contact between the cells and the $\mathrm{Ca}^{2+}$ fluorescence probe. The cells were then washed 2-3 times with $1 \mathrm{X}$ PBS and the cells were resuspended by adding $500 \mu \mathrm{l} 1 \mathrm{X}$ PBS. The $\mathrm{Ca}^{2+}$ concentration was detected with a flow cytometer (Beckman Coulter, Inc.). The data were analyzed with Summit v5.2 Software (Beckman Coulter, Inc.).

ATP and lactic acid (HL) detection. The detection of ATP content was performed using an ATP content test kit (S0026; Beyotime Institute of Biotechnology), according to the manufacturer's protocol. Relative light unit values were determined using a Luminometer. A standard curve was drawn and the ATP concentration of the sample to be tested was calculated. The measured concentration of ATP is divided by the concentration of the protein and the unit is finally converted to $\mathrm{nmol} / \mathrm{mg}$ protein. The detection of HL content was performed using a HL content test kit (Nanjing Jiancheng Bioengineering Institute, Nanjing, China), according to the manufacturer's protocol.

Cyclic AMP (cAMP) and adiponectin (ADP/acrp30) tests. A cAMP testkit (cat.no.E-EL-0056c; Elabscience, Wuhan, China) was used according to the manufacturer's protocols. The optical density (OD) of each well was measured immediately with a microplate reader at a wavelength of $450 \mathrm{~nm}$. A standard curve 
was drawn and the solubility was calculated from the curve. An ADP/acrp30 test kit (cat. no. E-EL-H0004c; Elabscience) was used according to the manufacturer's protocol. The OD of each well was measured immediately with a microplate reader at a wavelength of $450 \mathrm{~nm}$. A standard curve was drawn and the concentration was calculated from the curve.

$N A D P^{+} / N A D P H$ assay. For the extraction of $\mathrm{NADP}^{+}, 1 \mathrm{ml}$ acidic extract (Nanjing Jiancheng Bioengineering Institute) was added to $5 \times 10^{6}$ cells, and then the cells were sonicated for $1 \mathrm{~min}$, boiled $5 \mathrm{~min}$ at $100^{\circ} \mathrm{C}$, cooled in an ice bath at $4^{\circ} \mathrm{C}$ for $5 \mathrm{~min}$ and centrifuged at $10,000 \mathrm{x}$ for $10 \mathrm{~min}$ at $4^{\circ} \mathrm{C}$. The supernatant was extracted and an equal volume of alkaline extract (Nanjing Jiancheng Bioengineering Institute) was added to neutralize the cells. The cells were then mixed well at $10,000 \mathrm{x} \mathrm{g}$ for $10 \mathrm{~min}$ at $4^{\circ} \mathrm{C}$. Subsequently, reagent one to seven reagents (Nanjing Jiancheng Bioengineering Institute) was added and mixed well. Absorbance was measured at a wavelength of $570 \mathrm{~nm}$ and an optical path of $1 \mathrm{~cm}$. Following this, the $\mathrm{NADP}^{+}$content was calculated according to the formula: $\mathrm{NADP}^{+}=4.57 \times(\Delta \mathrm{A}-0.062) / \mathrm{Cpr}, \Delta \mathrm{A}=\mathrm{A} 2-\mathrm{A} 1$, where Cpr represents the concentration of protein, A1 represents the absorbance of the control group and A2 represents the absorbance of the experimental group. For the extraction of NADPH, $1 \mathrm{ml}$ alkaline extract was added to $5 \times 10_{6}$ cells, and then the cells were sonicated for $1 \mathrm{~min}$, boiled for $5 \mathrm{~min}$ at $100^{\circ} \mathrm{C}$, cooled in an ice bath at $4^{\circ} \mathrm{C}$ for 5 min and centrifuged at $10,000 \mathrm{x} \mathrm{g}$ for $10 \mathrm{~min}$ at $4^{\circ} \mathrm{C}$. The supernatant was extracted and an equal volume of acidic extract was added to neutralize the cells. The cells were then mixed well at $10,000 \mathrm{x} \mathrm{g}$ for $10 \mathrm{~min}$ at $4^{\circ} \mathrm{C}$. Subsequently, reagent one to seven reagents was added and mixed well. Absorbance was measured at a wavelength of $570 \mathrm{~nm}$ and an optical path of $1 \mathrm{~cm}$. Following this, the NADPH content was calculated according to the formula: $\mathrm{NADPH}=7.2 \times(\Delta \mathrm{A}-0.072) / \mathrm{Cpr}, \Delta \mathrm{A}=\mathrm{A} 2-\mathrm{A} 1$, where Cpr represents the concentration of protein, A1 represents the absorbance of the control group and A2 represents the absorbance of the experimental group.

Bioinformatics analysis. The NPC-associated dataset GSE13597 (31) based on GPL96 (HG-U133A) Affymetrix Human Genome U133A Array (32) was downloaded from the Gene Expression Omnibus (GEO) database (www.ncbi.nlm.nih. giv/geo/), including 25 NPC and 3 normal samples. The Empirical Bayes method (33) was used to select significant differentially expressed genes (DEGs) based on the limma (http://www.bioconductor.org/packages/release/bioc/html/limma.html) package of Bioconductor v3.6 (http://www.bioconductor.org/biocLite.R). In the volcano map, the DEGs with a fold change of $>2$ were selected. Kyoto Encyclopedia of Genes and Genomes (KEGG; http://www.kegg.jp/) enrichment analysis of DEGs was performed based on R software v3.4.1 (https://www.r-project. org/). Finally, Cytoscape software v3.6.0 (https://cytoscape.org/) was used to build protein-protein interaction (PPI) networks and module analyzes to determine the key genes.

Liquid chromatography-mass spectrometry (LC-MS)/MS analysis. A total of $5 \times 10^{5}$ cells were washed twice with PBS, and then $150 \mu \mathrm{l}$ radioimmunoprecipitation assay (RIPA) buffer (CWBIO, Beijing, China) was added. Following being lysed at $4^{\circ} \mathrm{C}$ for $1 \mathrm{~h}$, the cells were disrupted by sonication for $10 \mathrm{~min}$. Subsequently, the cells were centrifuged at $12,000 \mathrm{x} g$ for $15 \mathrm{~min}$ at $4^{\circ} \mathrm{C}$, and the supernatant was collected. Following this, the Coomassie Brilliant Blue method (34) was used for determination of protein concentration. Subsequently, the proteins were separated by western blot analysis. SDS-PAGE was stained with Coomassie Brilliant Blue on a shaker for $1 \mathrm{~h}$ at room temperature. The Coomassie blue-stained protein strip was cut into $1 \mathrm{~mm}^{3}$ size pellets, collected in Eppendorf ${ }^{\circledR}$ (EP) tubes, and washed three times with ultrapure water. Subsequently, $0.5 \mathrm{ml}$ decolorizing solution without gelatinous particles was added, decolorized at $37^{\circ} \mathrm{C}$ and the decolorizing solution was replaced once, until it became colorless and transparent, and was washed 3 times with $25 \mathrm{mM}$ $\mathrm{NH}_{4} \mathrm{HCO}_{3}$. Additionally, $0.5 \mathrm{ml} 100 \% \mathrm{ACN}$ was added, the cells were dried at $37^{\circ} \mathrm{C}$ for $5 \mathrm{~min}$, and then $250 \mu 125 \mathrm{mM}$ dithiothreitol (DTT) and $25 \mathrm{mM} \mathrm{NH}_{4} \mathrm{HCO}_{3}$ was added. Following this, the cells were incubated in a water bath at $56^{\circ} \mathrm{C}$ for $1 \mathrm{~h}$, and then the supernatant was aspirated. Immediately after cooling to room temperature for $3 \mathrm{~min}, 250 \mu \mathrm{l}$ protein protection solution ( $55 \mathrm{mM}$ IAA and $25 \mathrm{mM} \mathrm{NH}_{4} \mathrm{HCO}_{3}$ ) was added. The reaction was allowed to stand at room temperature for $30 \mathrm{~min}$ in the dark, and the supernatant was aspirated. Subsequently, $250 \mu 125 \mathrm{mM}$ DTT and $25 \mathrm{mM} \mathrm{NH}_{4} \mathrm{HCO}_{3}$ was added and allowed to react at room temperature for $30 \mathrm{~min}$ to remove excess IAA. Subsequently, washed 3 times with $0.5 \mathrm{ml}$ $25 \mathrm{mM} \mathrm{NH}_{4} \mathrm{HCO}_{3}$. Following this, the cells were dehydrated twice with $0.5 \mathrm{ml} 100 \% \mathrm{ACN}$, dried at $37^{\circ} \mathrm{C}$ for $5 \mathrm{~min}$ and then washed once with $0.5 \mathrm{ml} 25 \mathrm{mM} \mathrm{NH}_{4} \mathrm{HCO}_{3}$. After, the cells were dehydrated 2 times with $0.5 \mathrm{ml} 100 \%$ ACN, dried at $37^{\circ} \mathrm{C}$ for $5 \mathrm{~min}$, and then $0.5 \mathrm{ml}$ trypsin was added and incubated for $30 \mathrm{~min}$ at $4^{\circ} \mathrm{C}$. Following this, $0.5 \mathrm{ml} 25 \mathrm{mM} \mathrm{NH}_{4} \mathrm{HCO}_{3}$ was added and reacted at $37^{\circ} \mathrm{C}$ for $18 \mathrm{~h}$. Subsequently, the protein was centrifuged at $10,000 \mathrm{x}$ g for $5 \mathrm{~min}$ at $4^{\circ} \mathrm{C}$, the enzymatic solution was aspirated into a new EP tube and $100 \mu$ l extract $(0.1 \% \mathrm{TFA}$ and $70 \% \mathrm{ACN})$ was added to the original EP tube. The tube was then incubated in a $37^{\circ} \mathrm{C}$ constant temperature water bath for $30 \mathrm{~min}$, and shaken at room temperature for $15 \mathrm{~min}$ with an oscillator, underwent ultrasonication for $15 \mathrm{~min}$, and the extract and the enzymatic solution were combined in a new EP tube. The ZipTip C18 column was desalted and concentrated to $\sim 3 \mu 1$ in a freeze concentrator, and then $20 \mu 10.1 \%$ FA was added. Subsequently, Nano-LC LTQ Orbitrap ETD Mass Spectrometry was performed.

Western blot analysis. Total cellular protein was extracted with RIPA buffer, and then the bicinchoninic assay method was used for determination of protein concentration (Thermo Fisher Scientific, Inc.). A total of $50 \mu \mathrm{g}$ sample protein volume mixed with 5X loading buffer (cat. no. WB2001; Suzhou New Secco Biotechnology Co., Ltd., Suzhou, China) was used and boiled in water for $5 \mathrm{~min}$ at $100^{\circ} \mathrm{C}$ following loading. Proteins were separated in $10 \%$ SDS-PAGE gels and electroblotted onto nitrocellulose membranes (Hyclone; GE Healthcare Life Sciences, Logan, UT, USA). The membranes were blocked using Tris-buffered Tween-20 (25 mM Tris-HCl, $150 \mathrm{mM}$ $\mathrm{NaCl}, \mathrm{pH} 7.5$ and $0.05 \%$ Tween-20) containing 5\% non-fat milk at $4^{\circ} \mathrm{C}$ overnight followed by overnight incubation at $4^{\circ} \mathrm{C}$ with primary antibodies: Mouse anti-CD38 (Immunoway Biotechnology Company; 1:1,000 dilution; cat. no. YM0122); 
Table I. The difference in cluster of differentiation 38 expression between NPC and non-tumor nasopharyngeal epithelial tissues by immunohistochemistry.

\begin{tabular}{lccccc}
\hline Samples & $\begin{array}{c}\text { Negative } \\
(-)\end{array}$ & $\begin{array}{c}\text { Weak } \\
\text { positive }(+)\end{array}$ & $\begin{array}{c}\text { Positive } \\
(++)\end{array}$ & $\begin{array}{c}\text { Strong } \\
\text { positive }(+++)\end{array}$ & $\begin{array}{c}\chi^{2} \\
\text { P-value }\end{array}$ \\
NPC & $7(35 \%)$ & $3(15 \%)$ & $5(25 \%)$ & $5(25 \%)$ & 12.17 \\
$\begin{array}{l}\text { Non-tumor nasopharyngeal } \\
\text { epithelial tissues }\end{array}$ & $14(82.35 \%)$ & $3(17.65 \%)$ & 0 & 0 & 0.0068 \\
\hline
\end{tabular}

NPC, nasopharyngeal carcinoma.

mouse anti-cyclin dependent kinase 4 (CDK4; Wuhan Boster Biological Technology, Ltd., Wuhan, China; 1:500 dilution; cat. no. BM1572), rabbit anti-c-Jun N-terminal kinase 2 (Immunoway Biotechnology Company; 1:1,000 dilution; cat. no. YM3721), rabbit anti-B-cell lymphoma-2 (Bcl-2; Immunoway Biotechnology Company; 1:1,000 dilution; cat. no. YT0427), rabbit anti-signal transducer and activator of transcription 1 (STAT1; Immunoway Biotechnology Company; 1:1,000 dilution; cat. no. YT6124), rabbit anti-extracellular signal-regulated kinase (ERK; Immunoway Biotechnology Company; 1:500 dilution; cat. no. YT1622), mouse antitumor protein 53 (TP53; Wuhan Boster Biological Technology, Ltd.; 1:500 dilution; cat. no. BM0101), rabbit anti-Ezrin (Immunoway Biotechnology Company; 1:1,000 dilution; cat. no. YT1651), rabbit anti-cyclin D1 (Wuhan Boster Biological Technology, Ltd.; 1:500 dilution; cat. no. BM4272), rabbit anti-integrin subunit $\alpha 5$ (ITGA5; Wuhan Boster Biological Technology, Ltd.; 1:500 dilution; cat. no. BA1641-2), rabbit anti-AKT1 (Wuhan Boster Biological Technology, Ltd.; 1:500 dilution; cat. no. A00024), rabbit anti-GAPDH (Wuhan Boster Biological Technology, Ltd; 1:1,000 dilution; cat. no. A00227), rabbit anti-cluster of differentiation 24 (CD24; Immunoway Biotechnology Company; 1:1,000 dilution; cat. no. YT0741), rabbit anti-glucose transporter 1 (GLUT1; Immunoway Biotechnology Company; 1:1,000 dilution; cat. no. YT1928), rabbit anti-GLUT4 (Immunoway Biotechnology Company; 1:1,000 dilution; cat. no. YT5523), rabbit antitumor protein TP53 induced glycolysis regulatory phosphatase (Immunoway Biotechnology Company; 1:1,000 dilution; cat. no. YN2999), rabbit anti-succinate dehydrogenase complex flavoprotein subunit A (SDHA; Immunoway Biotechnology Company; 1:2,000 dilution; cat.no. YT4226), rabbit anti-dihydrolipoamide dehydrogenase (DLD; Wuhan Boster Biological Technology, Ltd.; 1:500 dilution; cat. no.PB0608), rabbit anti-ribonucleotide reductase regulatory subunit M2 (RRM2; Wuhan Boster Biological Technology, Ltd.; 1:300 dilution; cat. no. BM5490), rabbit anti-ATP synthase peripheral stalk subunit D (ATP5H; Wuhan Boster Biological Technology, Ltd.; 1:500 dilution; cat. no. PB0281), rabbit anti-ATP synthase F1 (ATP5F1; Wuhan Boster Biological Technology, Ltd.; 1:1,000 dilution; cat. no. A10633-1), rabbit anti-hypoxia inducible factor (HIF)-1 $\alpha$ (Wuhan Boster Biological Technology, Ltd.; 1:500 dilution; cat. no. BA0912-2), rabbit anti-sirtuin (SIRT1; Immunoway Biotechnology Company; 1:1,000 dilution; cat. no. YT4302), rabbit anti-SIRT2 (Immunoway Biotechnology Company; 1:1,000 dilution; cat. no. YT4303) and mouse anti-SIRT6
(Immunoway Biotechnology Company; 1:500 dilution; cat. no. YM1274). The membranes were incubated with anti-rabbit or anti-mouse HRP-conjugated secondary antibody at $37^{\circ} \mathrm{C}$ for $1 \mathrm{~h}$ (dilution 1:5,000; cat. nos. GAR0072 and GAM007, respectively; LiankeBio). Specific signals were visualized using an enhanced chemiluminescent detection system (Bio-Rad Laboratories, Inc., Hercules, CA, USA). Rabbit anti- $\beta$-tubulin was used as a loading control. The controls used were mouse anti- $\beta$-tubulin (Immunoway Biotechnology Company; 1:5,000 dilution; cat. no. YM3030) and rabbit anti- $\beta$-tubulin (Affinity Biosciences. Cincinnati, OH, USA; 1:5,000 dilution; cat. no. AF7011)

Statistical analysis. The association between the expression of CD38 and clinicopathological characteristics in NPC were tested using a $\chi^{2}$ test. The differences between the groups were analyzed using an unpaired Student's t-test when there were only two groups. All statistical analyses were performed using SPSS software (SPSS, Inc., Chicago, IL, USA). Some charts were produced with GraphPad Prism v5.01 (GraphPad Software, Inc., La Jolla, CA, USA). The error bars represent the mean \pm standard error of the mean. $\mathrm{P}<0.05$ was considered to indicate a statistically significant difference.

\section{Results}

CD38 is highly expressed in NPC. To detect the protein expression levels of the CD38 molecular in NPC and non-tumor nasopharyngeal epithelial tissues, 20 NPC and 17 non-tumor nasopharyngeal epithelial tissues were collected. Immunohistochemistry was performed to detect the expression of CD38. The results demonstrated that 7 samples were negative, 3 samples were weak positive, 5 samples were positive and the other 5 samples were strong positive in NPC tissues. In the control group, 14 samples were negative and 3 samples were weak positive. Of the samples, 65.0\% (13/20) had a positive expression of CD38 in NPC tissues and 17.6\% (3/17) had a positive expression in the adjacent non-cancerous tissues. Whereas, negative expression was exhibited in 35.0\% (7/20) and $82.4 \%(14 / 17)$ of NPC and the adjacent non-cancerous tissues, respectively $(\mathrm{P}<0.01)$. The present results demonstrated that CD38 was highly expressed in NPC (Fig. 1A and Table I).

CD38 promotes the proliferation of NPC cells. The immunohistochemistry results indicated that CD38 was highly expressed in NPC. Combined with our previous 
A
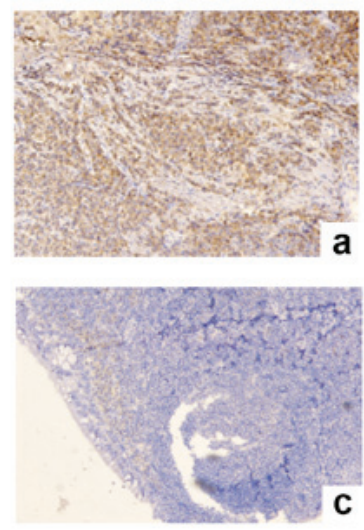
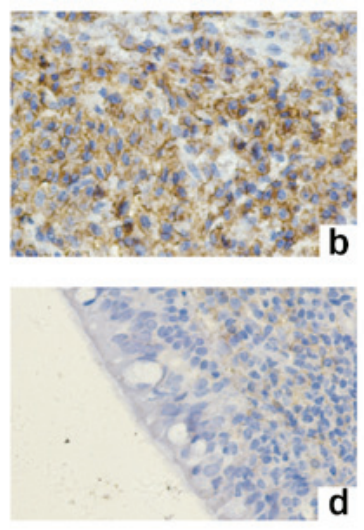

B

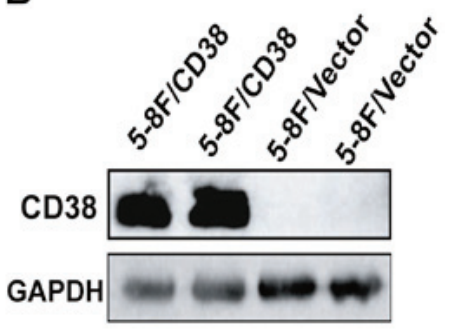

C

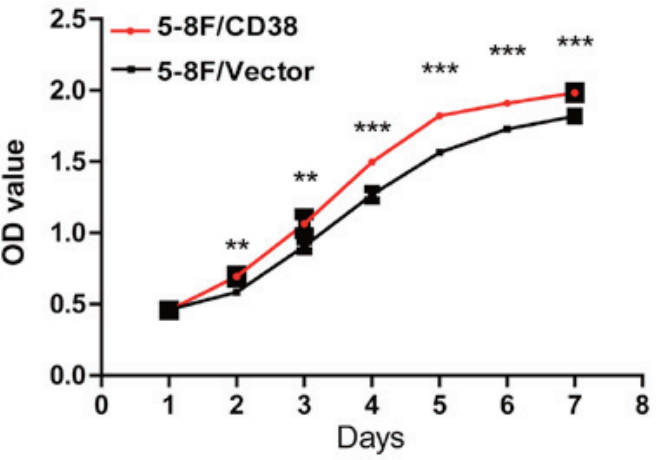

$\mathbf{E}$
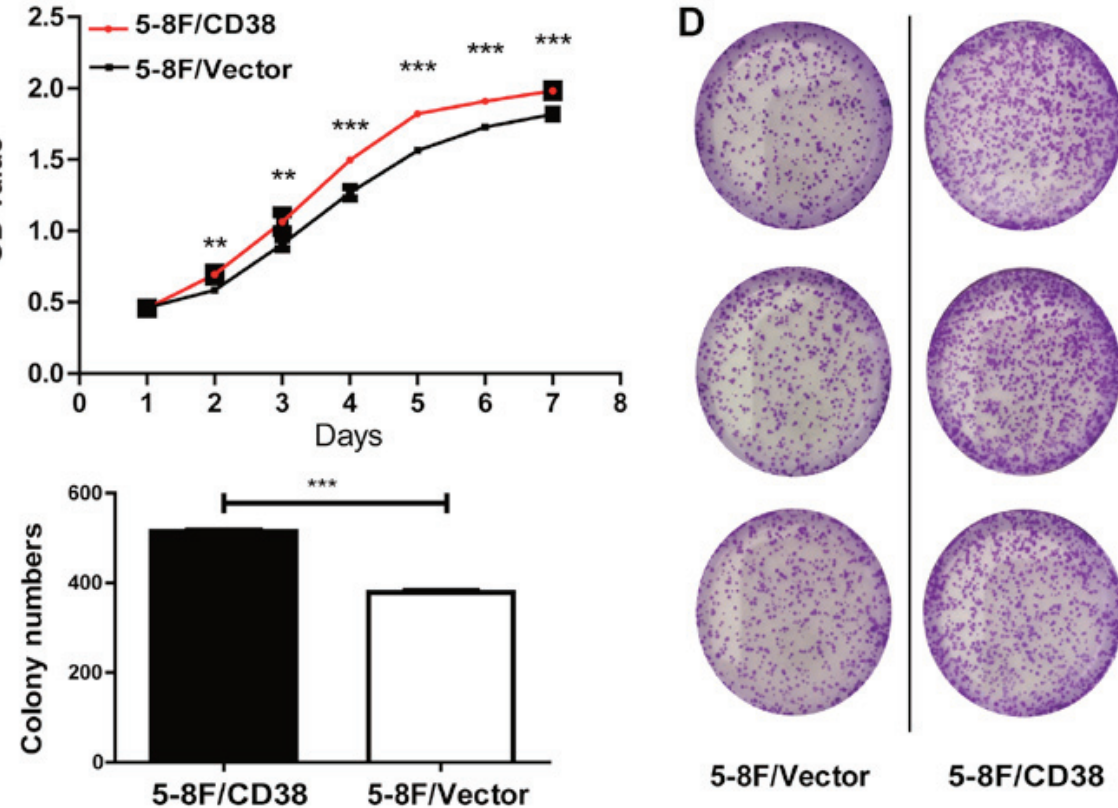

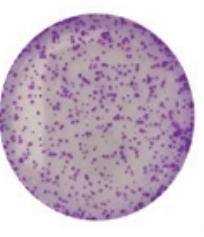

5-8F/Vector

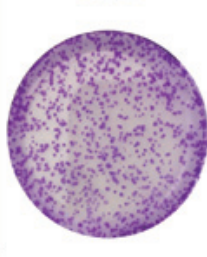

$5-8 F / C D 38$

Figure 1. Effect of CD38 on the cell proliferation of NPC cells. (A) The detection of expression levels of CD38 in the NPC tissues and non-tumor nasopharyngeal epithelial tissues by immunohistochemistry. Antibody of CD38 protein was used, and brown grains denote positive signal. (A-a) NPC tissue, x40. (A-b) Chronic inflammatory tissue, $x 40$. (A-c) NPC tissue, $x 200$. (A-d) Chronic inflammatory tissue, $x 200$. (B) The expression of CD38 protein in the 5-8F stable cell line was identified by western blot analysis and the results demonstrated that the CD38 overexpression stable cell line was successfully constructed. (C) The Cell Counting Kit-8 assay examined the proliferation of 5-8F/CD38 cells and 5-8F/Vector cells. The results demonstrated that CD38 can promote the proliferation of NPC 5-8F cells. P-values were calculated using a Student's t-test, compared with the vector group. (D) Colony formation assay was used to detect the clonogenic capacity of $5-8 \mathrm{~F}$ cells. (E) Statistical analysis of the colony formation assay. ${ }^{* *} \mathrm{P}<0.01$ and ${ }^{* * *} \mathrm{P}<0.001$. The error bars represent the mean \pm standard error of the mean. NPC, nasopharyngeal carcinoma; OD, optical density; CD38, cluster of differentiation 38 .

results, $\mathrm{CD} 38$ is a putative functional marker of side population (SP) cells in human NPC cell lines (35). It was speculated that $\mathrm{CD} 38$ served an important role in the pathogenesis of NPC. Thus, CD38-overexpressed-5-8F stable cell lines (5-8F/CD38; Fig. 1B) were successfully constructed. There are no difference between the $25-8 \mathrm{~F} / \mathrm{CD} 38$ columns in part $\mathrm{B}$, and there are no difference between the $25-8 \mathrm{~F} /$ Vector columns in part B. There is only one clone, and WB made 2 replicates. To clarify the effect of CD38 on the biological behavior of NPC cells, the effect of CD38 on the proliferation of 5-8F cells was examined using a CCK-8 assay. The results demonstrated that $\mathrm{CD} 38$ promoted the proliferation of $5-8 \mathrm{~F}$ cells (Fig. 1C). To further confirm that CD38 promotes the proliferation of NPC cells, a colony formation assay was performed. The results indicated that the high expression of CD38 clone number is increased, compared with the control group (Fig. 1D and E). These results demonstrate that CD38 promoted the proliferation of NPC cells.
CD38 not only promotes the migration of NPC cells, but also reduces the cell senescence of NPC cells. The migration of tumor cells serves an important role in tumor development $(36,37)$. In order to understand the impact of CD38 on the migration of tumor cells, a cell wound scratch assay was used to observe the cell scratch healing at different time points. It was determined that $5-8 \mathrm{~F} / \mathrm{CD} 38$ cells had an increased healing ability, compared with $5-8 \mathrm{~F} /$ Vector cells (Fig. 2A and B). To further validate these results, a Transwell assay was performed. Similarly, it was determined that $5-8 \mathrm{~F} / \mathrm{CD} 38$ cells had increased migration, compared with $5-8 \mathrm{~F} /$ Vector cells. The experiments demonstrated that CD38 promoted the migration of NPC cells (Fig. 2C and D).

The proliferative and differentiation abilities of cells gradually decline over time as the process of change progresses. Senescence also occurs in the tumor process $(38,39)$. Therefore, whether CD38 affects the senescence of NPC cells was further investigated by $\beta$-galactosidase staining. The results 
A
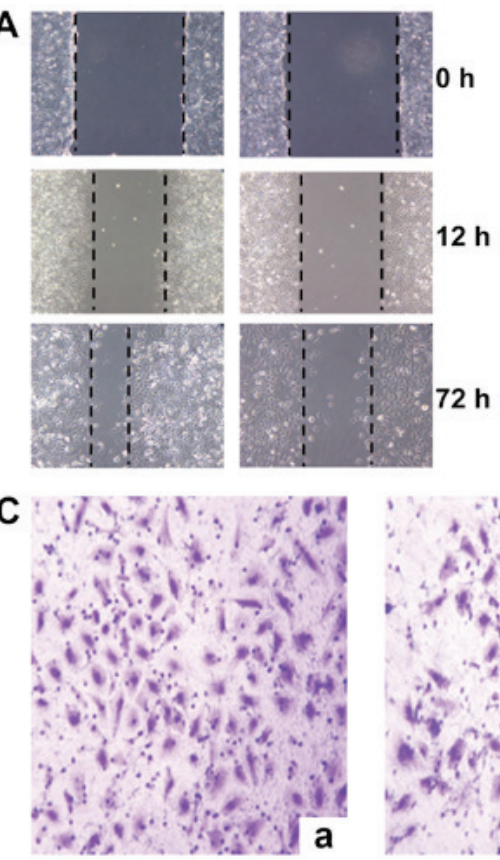

E
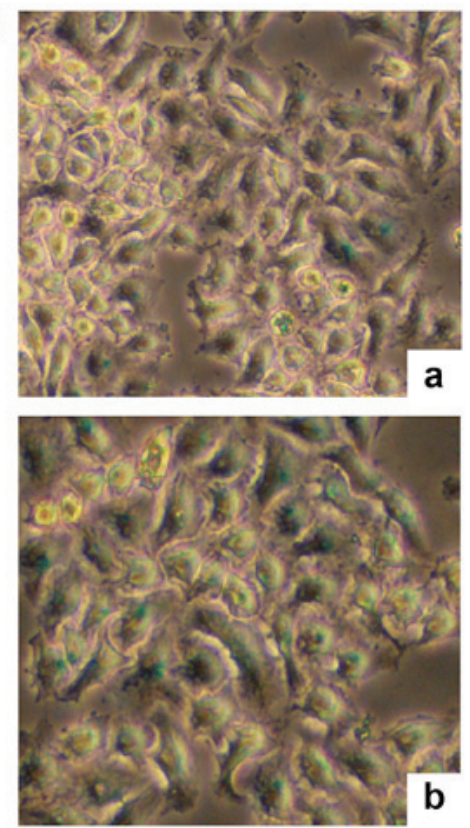

B
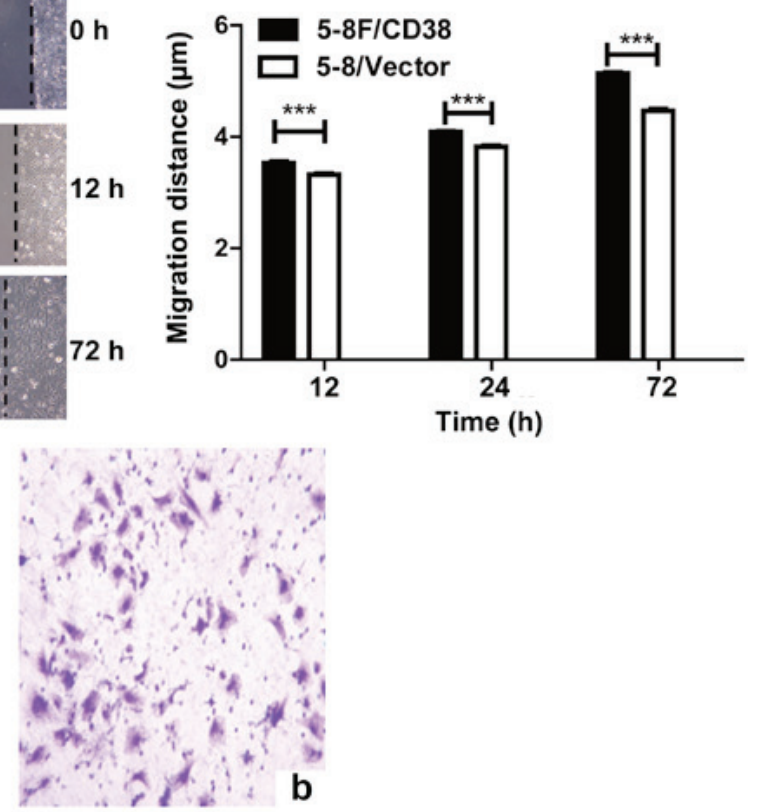

D

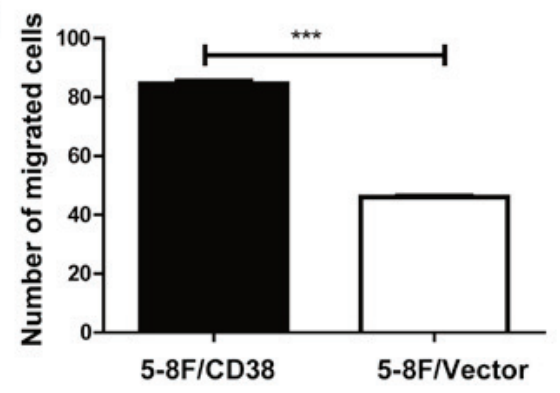

$F$

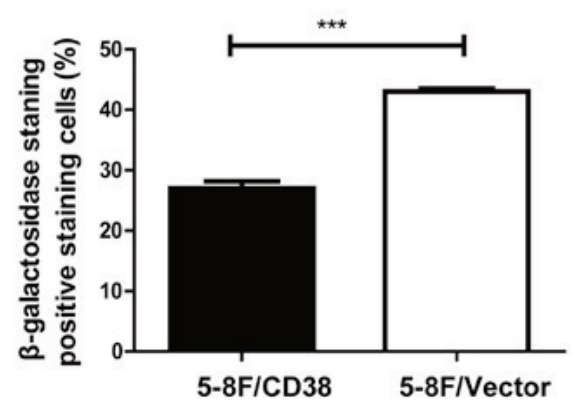

Figure 2. CD38 promotes cell migration and reduces cell senescence of NPC cells. (A) The migration of 5-8F-CD38/5-8F-Vector cells was examined with a scratch assay. CD38 could promote the migration of NPC 5-8F cells. (B) The difference was statistically significant between the 5-8F/CD38 and 5-8F/Vector groups. (C) A Transwell assay detected the migration of (C-a) 5-8F-CD38 and (C-b) 5-8F-Vector cells. (D) The Transwell assay of 5-8F-CD38 and 5-8F-Vector cell migration assay results. The results demonstrated that CD38 could enhance the migration ability of NPC 5-8F cells. The difference was statistically significant between the 5-8F/CD38 and 5-8F/Vector groups. (E) $\beta$-galactosidase staining demonstrated that CD38 overexpression can inhibit cell senescence, and was conducted on (E-a) 5-8F-CD38 and (E-b) 5-8F-Vector cells. The $\beta$-galactosidase positive cells (blue) were considered senescent. (F) Statistical analysis of $\beta$-galactosidase staining indicated that overexpression of CD38 inhibited cell senescence with statistical significance. ${ }^{* * *} \mathrm{P}<0.001$. The error bars represent the mean \pm standard error of the mean. PC, nasopharyngeal carcinoma; CD38, cluster of differentiation 38.

demonstrated that the number of $\beta$-galactosidase-positive 5-8F/CD38 cells was reduced, compared with 5-8F/Vector cells. Additionally, it was demonstrated that CD38 overexpression reduced cellular senescence in NPC cells (Fig. 2E and F).

CD38 affects the cycle distribution of NPC cells. The effect of CD38 overexpression on the cell cycle of NPC cells was further examined. Additionally, the cell cycle distribution of 5-8F/CD38 and $5-8 \mathrm{~F} /$ Vector cells was investigated with flow cytometry. The results demonstrated that $32.24 \%$ of $5-8 \mathrm{~F} / \mathrm{CD} 38$ cells were within the G0/G1 phase and $67.76 \%$ of $5-8 \mathrm{~F} / \mathrm{CD} 38$ cells were within the $\mathrm{S} / \mathrm{G} 2$ phase. However, $41.69 \%$ of $5-8 \mathrm{~F} / \mathrm{Vector}$ cells were within the $\mathrm{G} 0 / \mathrm{G} 1$ phase and $58.32 \%$ of $5-8 \mathrm{~F} /$ Vector cells were within the $\mathrm{S} / \mathrm{G} 2$ phase. Compared with the control group, the proportion of $5-8 \mathrm{~F} / \mathrm{CD} 38$ cells in the $\mathrm{S}$ phase was significantly increased. This demonstrated that CD38 promoted $S$ phase DNA replication and promoted the proliferation of NPC cells (Fig. 3A and B).

CD38 suppresses the cell apoptosis of NPC cells. Apoptosis was detected using a Hoechst 33342/PI double staining assay 

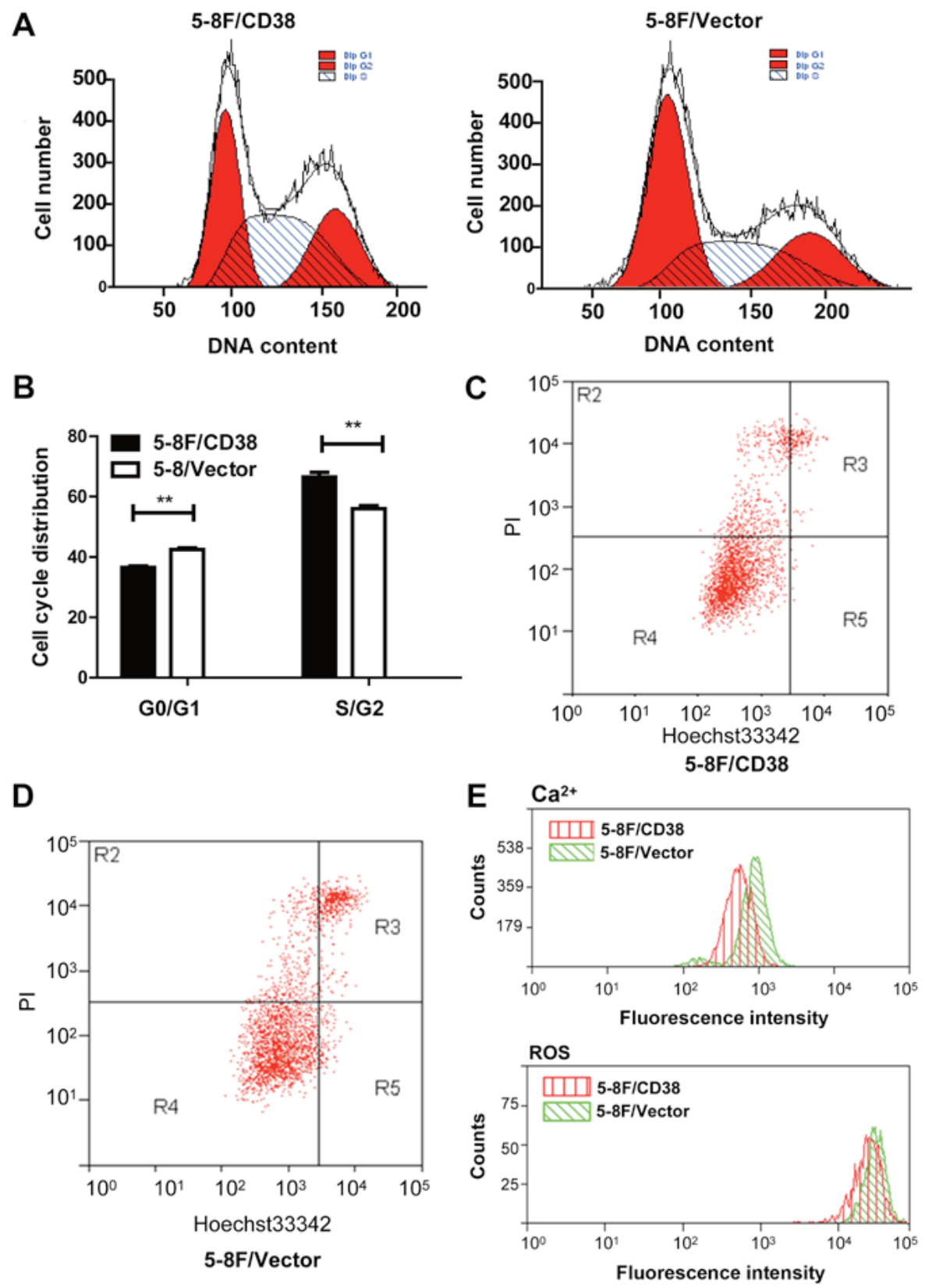

Figure 3. Detection of cell cycle, cell apoptosis, and $\mathrm{Ca}^{2+}$ and intracellular ROS concentrations in the NPC cell line, 5-8F, with flow cytometry. (A) Cell cycle distribution of 5-8F cells was examined with flow cytometry. (B) The results of flow cytometry demonstrated that CD38 could affect the cycle distribution of $5-8 \mathrm{~F}$ cells in NPC and promote the conversion of cells to the $\mathrm{S}$ phase. The difference was statistically significant between the $5-8 \mathrm{~F} / \mathrm{CD} 38$ and $5-8 \mathrm{~F} / \mathrm{Vector}$ groups. "P $<0.05$. (C and D) Effect of CD38 on apoptosis of NPC cells detected by PI/Hoechst 33342 double staining. (E) Flow cytometry was used to detect the concentration of $\mathrm{Ca}^{2+}$ and to detect ROS content. The error bars represent the mean \pm standard error of the mean. NPC, nasopharyngeal carcinoma; CD38, cluster of differentiation 38; ROS, reactive oxygen species; PI, propidium iodide.

and established 5-8F/CD38 cells were analyzed with flow cytometry. Concentrated chromatin in Hoechst 33342-stained apoptotic cells is more pronounced than in normal chromatin, and PI can only pass through dead cells and late apoptotic cells. Therefore, dyeing patterns distinguish normal, apoptotic and dead cell populations (40). As depicted in Fig. 3C and D, the percentage of apoptotic 5-8F/CD38 cells was reduced, compared with $5-8 \mathrm{~F} /$ Vector cells. The results indicated that CD38 inhibited cell apoptosis, which echoes the results in Fig. 2E.

CD38 regulates the intracellular $\mathrm{Ca}^{2+}$ concentration and $\mathrm{ROS}$ of NPC cells. In order toinvestigate the mechanism ofCD38 inhibited apoptosis of NPC cells, the intracellular $\mathrm{Ca}^{2+}$ concentration was detected by Fluorescein-2 AM, a $\mathrm{Ca}^{2+}$ ion fluorescent probe. The result was depicted in Fig. 3E. Compared with the 5-8F/Vector cells, 5-8F/CD38 cells had reduced fluorescence intensity. The results indicated that $5-8 \mathrm{~F} / \mathrm{CD} 38$ decreased intracellular $\mathrm{Ca}^{2+}$ concentration. Subsequently, DCFH-DA, a ROS detection probe, was used to further analyze the effect of CD38 overexpression on ROS production in NPC cells with flow cytometry. The results demonstrated that CD38 overexpression resulted in decreased levels of ROS in NPC cells (Fig. 3E)

CD38 affects the ATP concentration of NPC cells. In order to clarify the effect of CD38 on the ATP concentration of NPC 

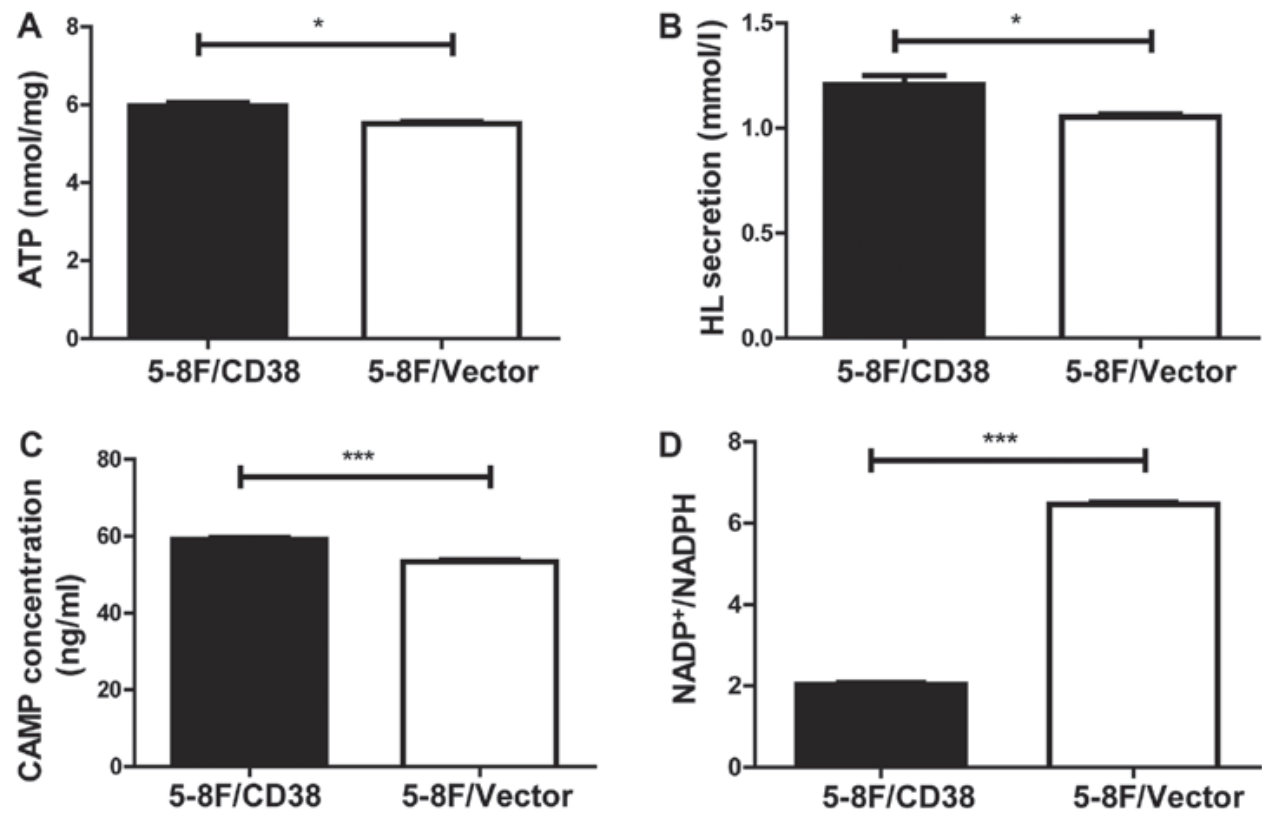

Figure 4. Detection of ATP, HL, cAMP level in NPC cell line 5-8F. (A) The results demonstrated that the intracellular ATP level was significantly increased in $5-8 \mathrm{~F} / \mathrm{CD} 38 \mathrm{NPC}$ cells, compared with the $5-8 \mathrm{~F} /$ Vector group. (B) The concentration of HL level was significantly increased in $5-8 \mathrm{~F} / \mathrm{CD} 38 \mathrm{NPC}$ cells, compared with the 5-8F/Vector group. (C) Detection of cAMP concentration in 5-8F/CD38 and 5-8F/Vector NPC cell lines. The results indicated that the intracellular cAMP level was increased in 5-8F/CD38 NPC 5-8F cells, compared with the 5-8F/Vector group. (D) Detection of NADP $/ \mathrm{NADPH}$ in 5-8F/CD38 and $5-8 \mathrm{~F} /$ Vector NPC cells. ${ }^{~} \mathrm{P}<0.05$ and ${ }^{* * *} \mathrm{P}<0.001$. The error bars represent the mean \pm standard error of the mean. NPC, nasopharyngeal carcinoma; CD38, cluster of differentiation 38; cAMP, cyclic AMP; HL, lactic acid.

cells, an ATP assay was used to detect the ATP concentration of $5-8 \mathrm{~F}$ cells. The results demonstrated that the concentration of ATP in 5-8F/CD38 cells was significantly increased, compared with 5-8F/Vector cells (Fig. 4A). Simultaneously, the results indicated that CD38 overexpression significantly increased HL levels of 5-8F cells, compared with 5-8F/Vector cells (Fig. 4B).

CD38 increases the intracellular cAMP concentration of $N P C$ cells. Cell proliferation and differentiation are two basic characteristics of cells. Cell proliferation and differentiation is a simultaneous and contradictory biological process. cAMP serves an important role in the regulation of these contradictions $(41,42)$. To clarify how CD38 affects the concentration of cAMP in NPC cells, cAMP was tested and it was determined that the concentration of cAMP in 5-8F/CD38 cells was $60.25 \pm 3.23 \mathrm{ng} / \mathrm{ml}$, and the $5-8 \mathrm{~F} /$ Vector intracellular cAMP concentration was $53.48 \pm 2.49 \mathrm{ng} / \mathrm{ml}$. Therefore, the cAMP concentration of $5-8 \mathrm{~F} / \mathrm{CD} 38$ cells was significantly increased, compared with 5-8F/Vector cells (Fig. 4C).

$C D 38$ reduces the intracellular $N A D P^{+} / N A D P H$ concentration of NPC cells. NADP ${ }^{+} / \mathrm{NADPH}$ is an important indicator of energy metabolism. NADP ${ }^{+} / \mathrm{NADPH}$ ratio is not only one of the major markers of cellular redox status, but also serves an important regulatory role in the pentose phosphate pathway and antioxidant metabolism (43). Therefore, whether CD38 affected $\mathrm{NADP}^{+} / \mathrm{NADPH}$ in NPC cells was further investigated. The results demonstrated that $\mathrm{NADP}^{+} / \mathrm{NADPH}$ significantly decreased in NPC cells following CD38 overexpression, compared with 5-8F/Vector cells (Fig. 4D).

CD38 affects the human ADP/acrp30 concentration of NPC cells. Human ADP/acrp30, which activates the signaling pathway associated with cAMP-protein kinase A, has an inhibitory function in activation of nuclear factor- $\kappa B$ and intercellular adhesion molecule, as well as vascular endothelial cells (44). In order to clarify the effect of CD38 on the ADP/acrp30 concentration in NPC cells, an ADP/acrp30 kit was used to detect the concentration of ADP/acrp30 in $5-8 \mathrm{~F} / \mathrm{CD} 38$ and $5-8 \mathrm{~F} / \mathrm{Vector}$ cells. The concentration of ADP/acrp30 in 5-8F/CD38 cells was $0.89 \pm 0.10 \mathrm{ng} / \mathrm{ml}$ and the concentration of $\mathrm{ADP} / \mathrm{acrp3} 3$ in the $5-8 \mathrm{~F} /$ Vector cells was $0.76 \pm 0.04 \mathrm{ng} / \mathrm{ml}(\mathrm{P}>0.05)$. The results remonstrated that the concentration of $\mathrm{ADP} / \mathrm{acrp} 30$ in $5-8 \mathrm{~F} / \mathrm{CD} 38$ cells was increased, compared with $5-8 \mathrm{~F} /$ Vector cells, but the difference was not statistically significant (Fig. 5A).

Bioinformatics analysis of high-throughput data. To determine the most notably changing molecule and signaling pathway, the scientific information retrieval from the GEO database was used to download the GSE13597, which contained 28 samples, including 25 NPC samples and 3 control samples. Analysis of the results determined a total of 910 DEGs, such as RRM2, $\zeta$ chain of T-cell receptor-associated protein kinase 70 (ZAP70), TP53 and SDHA, including 210 significantly downregulated DEGs and 266 significantly upregulated DEGs (fold change $>2$; Fig. 5B). Subsequently, KEGG enrichment and PPI analysis of significantly DEGs was performed (Fig. 5C-E). KEGG pathway analysis determined five significantly enriched pathways: DEGs enriched in cell cycle, DNA replication, TP53 signaling pathway, pathway in cancer and small cell lung cancer. PPI analysis demonstrated interactions between upregulated DEGs and interactions between downregulated DEGs, including, gene CDK4 and minichromosome maintenance complex component 6 interacting with each other in upregulated DEGs, and ZAP70 

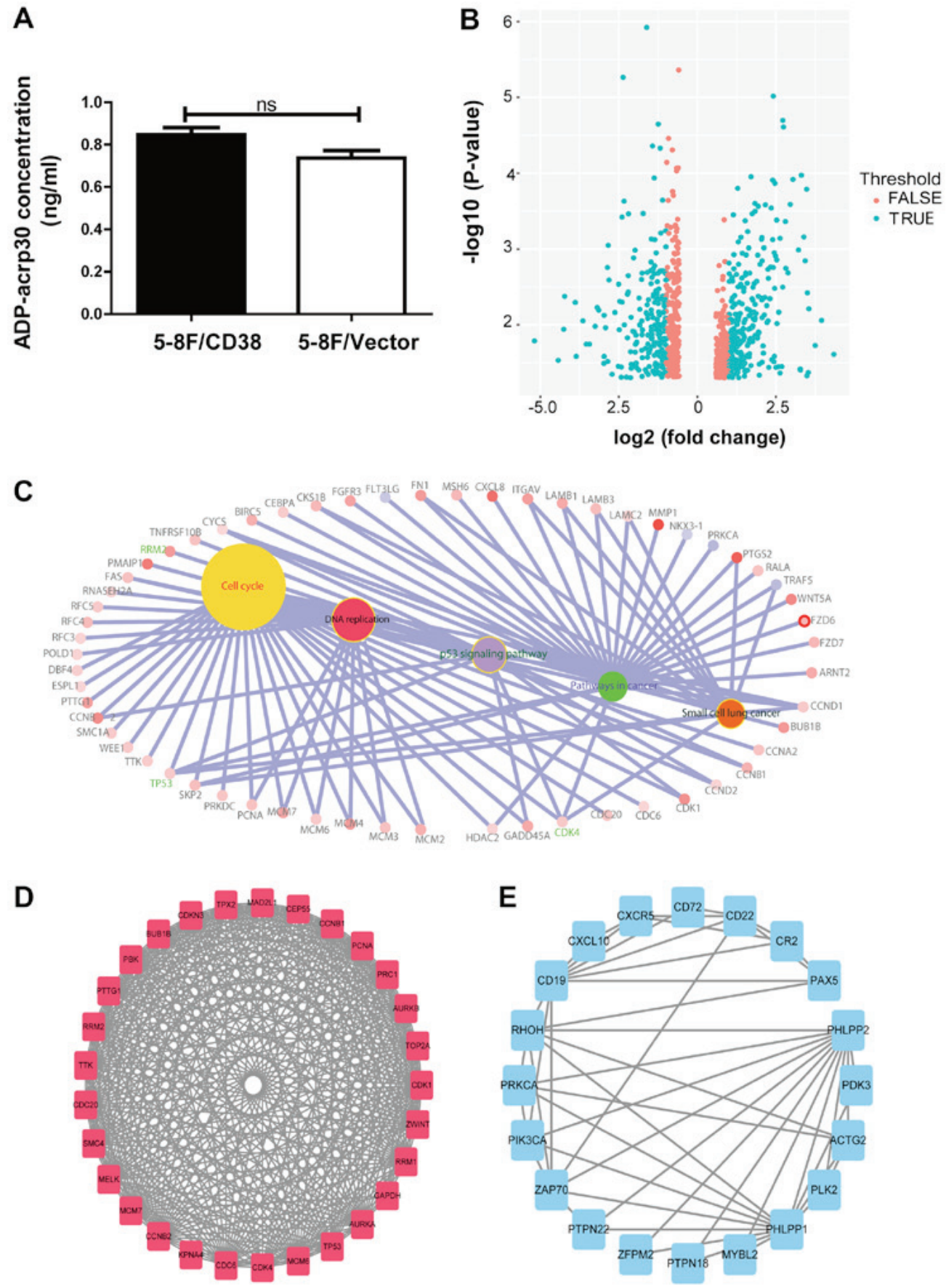

Figure 5. Bioinformatics analysis of high-throughput data. (A) Detection of ADP/acrp30 concentrations in 5-8F/CD38 and 5-8F/Vector NPC cells. The results demonstrated that the expression of ADP/acrp30 in NPC 5-8F cells was increased following overexpression of CD38, compared with the 5-8F/CD38 group (B) Volcano plot of 476 DEGs. Turquoise represents the fold change value of DEGs $>2$, and red represents the fold change value of DEGs $<2$ in GSE13597. (C) The significantly enriched Kyoto Encyclopedia of Genes and Genomes pathways of DEGs. (D) The upregulated DEGs with highest connectivity degree of PPI network. Red represents upregulation. (E) The downregulated DEGs with highest connectivity degree of PPI network. Blue represents downregulation. The error bars represent the mean \pm standard error of the mean. ADP/acrp30, adiponectin; DEG, differentially-expressed genes; NPC, nasopharyngeal carcinoma; CD38, cluster of differentiation 38; PPI, protein-protein interaction; ns, not significant.

and protein tyrosine phosphatase, non-receptor type 22 interacting with each other in downregulated DEGs.

CD38 affects the biological behavior and energy metabolism of NPC cells by downregulating TP53, and upregulating $H I F-1 \alpha$, SIRT1 and SDHA. Based on the previous results, western blot analysis was selected for validation of DEGs associated with cellular energy metabolism, cell proliferation and apoptosis. It was determined that CD38 overexpression yielded unexpected results. Upregulation of cell proliferation-associated genes CDK4, mitogen-activated protein kinase 9 and Cyclin D1 progressed the cell cycle from the $\mathrm{G} 1$ phase to the $\mathrm{S}$ phase resulting in increased cell proliferation. Although GADPH was a DEG that was upregulated, following CD38 overexpression, western blot analysis demonstrated that GAPDH was downregulated. Subsequently, western blot analysis of DEGs associated with cell apoptosis was performed. It was determined Bcl-2 and 

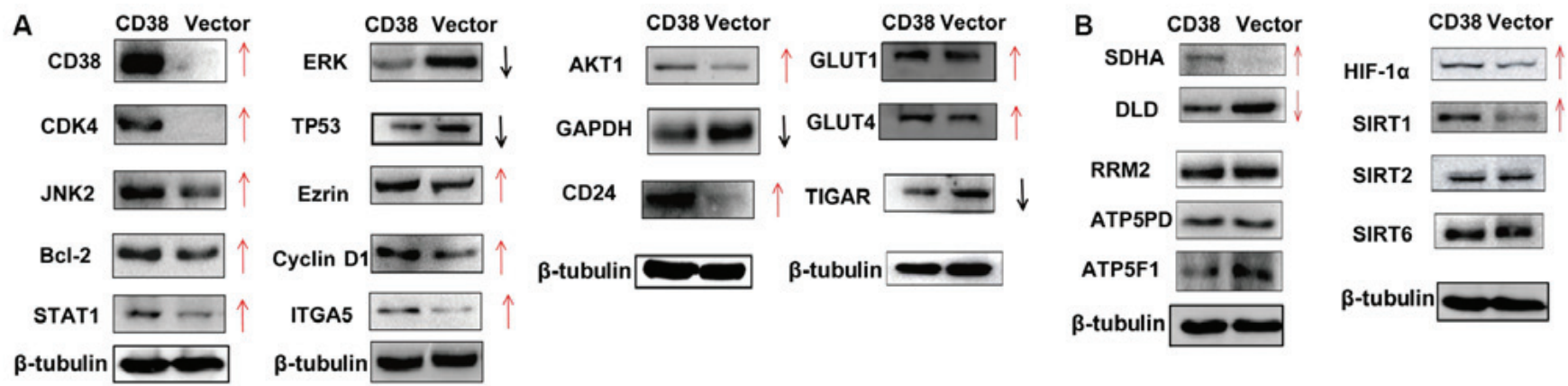

Figure 6. Verification of differential molecules by western blot analysis. (A) The expression of CDK4, JNK2, TP53, CD24 and other genes in NPC 5-8F/CD38 and 5-8F/Vector cells by western blot analysis. CD38, CDK4, JNK2, Bcl-2 and STAT1 are from the same membrane. ERK, TP53, Ezrin, Cyclin D1 and ITGA5 are from the same membrane. AKT, GAPDH and CD24 are from the same membrane. GLUT1, GLUT4 and TIGAR are from the same membrane. (B) The expression of HIF-1 $\alpha$, SIRT1, SIRT6 and SDHA in NPC 5-8F/CD38 and 5-8F/Vector cells by western blot analysis. SDHA, DLD, RRM2, ATP5PD and ATP5F1 are from the same membrane. HIF-1 $\alpha$, SIRT1, SIRT2, SIRT6 are from the same membrane. NPC, nasopharyngeal carcinoma; CD38, cluster of differentiation 38; CDK4, cyclin-dependent kinase 4; JNK2, mitogen-activate protein kinase 9; Bcl-2, B-cell lymphoma-2; STAT1, signal transducer and activator of transcription 1; ERK, extracellular regulated kinase; ITGA5, integrin subunit $\alpha 5$; GLUT1, glucose transporter 1; TIGAR, tumor protein TP53 induced glycolysis regulatory phosphatase; SDHA, succinate dehydrogenase complex flavoprotein subunit A; DLD, dihydrolipoamide dehydrogenase; RRM2, ribonucleotide reductase regulatory subunit M; ATP5PD, ATP synthase peripheral stalk subunit D; ATP5F1, ATP synthase F1; HIF-1 $\alpha$, hypoxia inducible factor-1 $\alpha$; SIRT1, sirtuin 1.

Ezrin expression was upregulated and TP53 expression was downregulated following CD38 overexpression. This implied that $5-8 \mathrm{~F} / \mathrm{CD} 38$ inhibited the cell apoptosis, consistent with the results depicted in Fig. 3E. Simultaneously, the DEGs ERK, STAT1, ITGA5, CD24 $(45,46)$ and AKT1, which serve important regulatory roles in cell growth, cell activation and cell signaling (47), were identified with western blot analysis. The results demonstrated that ERK was downregulated, and STAT1, ITGA5, CD24 and AKT1 were upregulated (Fig. 6A).

HIF- $1 \alpha$ induces glycolysis by binding to the DNA binding site on the target gene, increasing the glycolysis process. It promotes anaerobic metabolism and facilitates glycolysis of tumor cells under hypoxic conditions. SIRT1, SIRT2 and SIRT6 molecules belong to the $\mathrm{NAD}^{+}$dependent III histone deacetylase sirtuin family $(48,49)$. Therefore, in order to investigate the possible mechanism of CD38 on the metabolism of $5-8 \mathrm{~F}$ cells, the expression of HIF- $1 \alpha$, SIRT1, SIRT2 and SIRT6 in 5-8F/CD38 and 5-8F/Vector cells was detected with western blot analysis. The results of LC-MS/MS identified 329 DEGs in 5-8F/CD38 cells, including 52 molecules associated with energy metabolism, such as SDHA, ATP5PD, ATP5F1, RRM2 and DLD, which were upregulated. The results demonstrated that CD38 overexpression upregulated the expression of SDHA and downregulated the expression of DLD, but had no significant effect on the expression of ATP5PD, ATP5F1 and RRM2 (Fig. 6B).

In conclusion, CD38 affects the biological behavior and energy metabolism of NPC cells by regulating the expression of TP53, HIF-1 $\alpha$, SIRT1, SDHA and other genes.

\section{Discussion}

CD38 is a cell surface enzyme that serves an important role in various physiological processes, including immune response, inflammation, cancer and metabolic diseases (50-52). CD38 is a multifunctional molecule, and has a number of complex and unique biological characteristics and functions, including: i) Receptor characteristics $(53,54)$; ii) enzyme activity function (55); iii) adhesion molecule properties (56); iv) cell activation and cytokine production $(57,58)$; and v) vector function (59). Previously, CD38 molecules have been demonstrated to be involved in the regulation of a number of physiological and pathological processes, including signal transduction (60), synthesis of cyclic ADP-ribose (61) and the cell cycle (62). In multiple myeloma, CD38 is an important therapeutic target for multiple myeloma (24). Our previous study also determined that CD38 was highly expressed in the SP of NPC and that CD38 may be involved in the regulation of the proliferation and invasion of SP cells by interacting with ZAP70 (36).

In the present study, the results demonstrated that CD38 was highly expressed in NPC tissues, compared with non-tumor nasopharyngeal epithelial tissues. It was speculated that there may be associations between CD38 expression and the clinical characteristics of patients; however, sufficient samples have no been collected yet. In future experiments, sufficient information and samples will be collected in this regard. CD38 promoted the proliferation of $5-8 \mathrm{~F}$ cells and significantly increased the clonogenic capacity of $5-8 \mathrm{~F}$ cells. Flow cytometry demonstrated that $\mathrm{CD} 38$ promoted $\mathrm{S}$ phase DNA replication of NPC cells and promoted the proliferation of NPC cells. CD38 overexpression served an inhibitory role in the apoptosis of $5-8 \mathrm{~F}$ cells. Abnormal changes in the process of apoptosis causes a variety of diseases $(63,64)$, for example, T-cell resistance against apoptosis contributes to inappropriate T-cell accumulation and the perpetuation of the chronic inflammatory process in inflammatory bowel disease with potential tumorigenic effect. Excessive apoptosis causes atrophy, and reduced apoptosis results in abnormal cell proliferation and tumorigenesis (65). A number of studies demonstrated that in the mouse model, CD38 regulated microglia activation, and the lack of CD38 slowed the process of glioma, reduced tumor expansion and prolonged the life of tumor-bearing mice $(57,66,67)$. The lack of CD38 is associated with increased cell death and reduced expression of metalloproteinase-12 in the tumor mass (57). In a mouse esophageal cancer model, CD38-overexpressing myeloid-derived suppressor cells (MDSCs) were determined to be less mature than MDSCs with low CD38 expression. Furthermore, high 


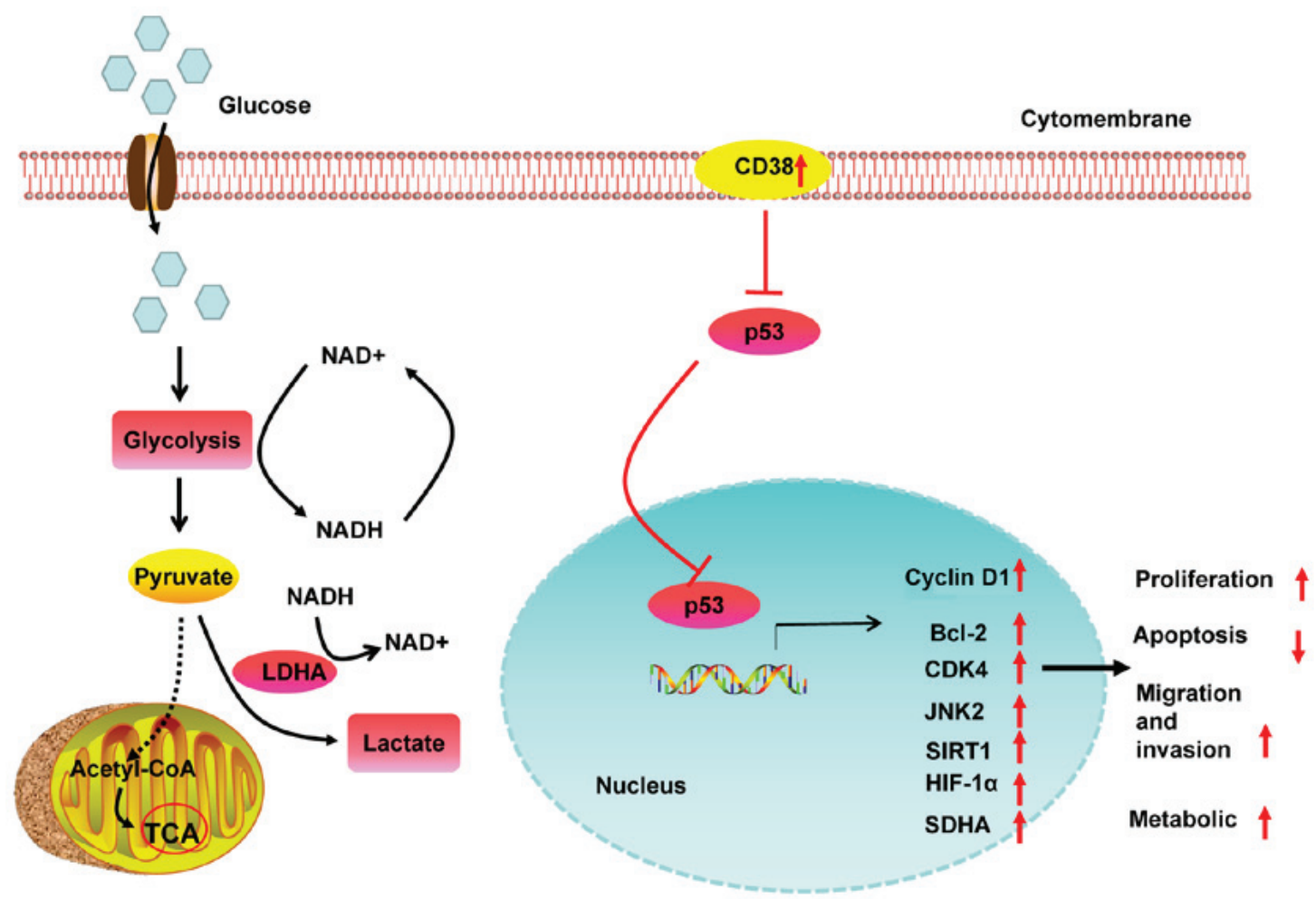

Figure 7. CD38 regulates the molecular mechanisms involved in energy metabolism. Bcl-2, B-cell lymphoma-2; CDK4, cyclin-dependent kinase 4; JNK2, mitogen-activate protein kinase 9; SIRT1, sirtuin 1; HIF-1 $\alpha$, hypoxia inducible factor-1 $\alpha$; SDHA, succinate dehydrogenase complex flavoprotein subunit A; acetyl-coA, acetyl coenzyme A; TCA, tricarboxcylic acid cycle; LDHA, lactate dehydrogenase A; CD38, cluster of differentiation 38.

CD38 expression in MDSCs caused an increased inhibitory effect on activated $\mathrm{T}$ cells, and it promoted increased tumor growth (68). Liao et al (53) determined that CD38 was highly expressed in cervical cancer tissues and affects the expression of phosphoinositide 3-kinase (PI3K), AKT, mouse double minute 2 proto-oncogene and TP53 in cervical cancer cells, indicating that CD38 serves a role in regulating the PI3K/AKT signaling pathway in cervical cancer. It has been reported that knockout of CD38 causes increased cell apoptosis in hairy cell leukemia (HCL), and inhibits the adhesion of HCL cells to monolayer epithelial cells, destroying their ability to form tumors (69). Overexpression of CD38 promoted the proliferation of NPC cells and inhibited the apoptosis in NPC cells. However, a number of studies demonstrated that CD38 exerted its antitumor effect in malignant tumors (69,70). Chini et al (71) determined that CD38 was the major consumption enzyme of NAD. Overexpression of CD38 resulted in the arrest of pancreatic cancer cells and the increase of cell senescence. Additionally, CD38 serves an important role by inhibiting nicotinamide phophoribosyltransferase.

Cyclin D1 serves an important role in cell cycle progression and is one of the key molecules that regulate the G1 restriction point in cell cycle progression (72-74). There is evidence that Cyclin D1 protein expression is vital for normal cell cycle progression (72). Abnormal expression of Cyclin D1 may disrupt cell cycle regulation, resulting in increased genomic instability and tumor induction $(75,76)$. The aforementioned results are similar to those in the present study, confirming the role of Cyclin D1 and CDK molecules in the biological behavior of $5-8 \mathrm{~F} / \mathrm{CD} 38$ cells.

In prokaryotes, cAMP may directly activate RNA polymerase in order to promote its transcription, through the 6-factor phosphorylation level of the enzyme, to promote the transcription level of RNA. Recent studies demonstrated that the role of cAMP in eukaryotic cells was determined to be associated with regulation of transcription factors $(77,78)$, for example, gene expression patterns define key transcriptional events in cell-cycle regulation by cAMP and protein kinase A. cAMP has the effect of inhibiting its cell division and promoting cell differentiation $(41,42)$. cAMP also has a dual effect on cell proliferation, which promotes cell proliferation at early G0 or G1, and is inhibited at late G1 (42). The present study determined that the cAMP concentration of $5-8 \mathrm{~F} / \mathrm{CD} 38$ cells was increased, compared with $5-8 \mathrm{~F} /$ Vector cells, indicating that CD38 affects the concentration of cAMP in NPC cells. Human ADP/acrp30 can increase the survival of the majority of endothelial progenitor cells in vitro, and inhibit the apoptotic process. The role of human ADP/acrp30 is primarily focused on endothelial cells affecting angiogenesis (79). A previous study also determined that human ADP/acrp30 had the effect of inhibiting mature macrophages, including the ability to inhibit the phagocytosis of mature macrophages $(80,81)$. The present results demonstrated that CD38 overexpression had no significant effect on 5-8F cell intracellular concentrations of ADP/acrp30 in NPC.

HIF-1 $\alpha$ regulates the transcriptional activity and expression of different target genes in the body, participates in invasion, metastasis and the production of blood vessels (82). The overexpression of HIF- $1 \alpha$ is associated with the poor prognosis of a number of malignant tumors types (83-85), for example, HIF-1a is critical for the inhibitory effect of oleanolic acid on rectal cancer cell proliferation. The present results demonstrated that CD38 overexpression resulted in the upregulation of HIF-1 $\alpha$. 
This indicated that CD38 may participate in the proliferation and cell metabolism of NPC cells by affecting the activity of HIF-1 $\alpha$. HIF- $1 \alpha$ can also participate in tumor angiogenesis through the regulation of vascular endothelial growth factor expression and promoting tumor cell metastasis $(48,86)$.

In the present study, it was demonstrated that CD38 overexpression inhibited cell apoptosis and promoted cell proliferation in NPC cells. It was determined that CD38 may promote cell proliferation through inhibiting TP53, causing the upregulation of CDK4 and Cyclin D1 protein expression, thus promoting the transition from G1 to $\mathrm{S}$ phases. It was indicated that CD38 inhibition of apoptosis may be through inhibition of TP53, and also that Bcl-2 protein expression increased. It was demonstrated that CD38 regulated cellular energy metabolism by upregulating SIRT1, SDHA and HIF-1 $\alpha$ protein expression (Fig. 7). In conclusion, the present results indicated that CD38 may serve its carcinogenic effect on NPC by regulating the metabolic-associated signaling pathways.

\section{Acknowledgements}

Not applicable.

\section{Funding}

The present study was supported by National Natural Sciences Foundation of China (grant nos. 81672685, 81402270 and 81672993), the 111 Project (grant no. 111-2-12), the Natural Science Foundation of Xinjiang Autonomous Region (grant no. 2017D01C122), and the Planned Project of Key Subject Construction of the third Xiangya Hospital, Central South University.

\section{Availability of data and materials}

All data generated or analyzed during this study are included in this published article.

\section{Authors' contributions}

YZ designed the study. YG and YL conducted the experiments. SX, LL, ZH, CY and XW analyzed the data. The manuscript was drafted by YG and YZ. All authors read and approved the final manuscript.

\section{Ethics approval and consent to participate}

Written informed consent was obtained from each patient and experimental protocols were approved by the Institutional Review Board of the Hunan Provincal Tumor Hospitals (Changsha, China).

\section{Patient consent for publication}

All participants provided written informed consent for publication.

\section{Competing interests}

The authors declare that they have no competing interests.

\section{References}

1. Spano JP, Busson P, Atlan D, Bourhis J, Pignon JP, Esteban C and Armand JP: Nasopharyngeal carcinomas: An update. Eur J Cancer 39: 2121-2135, 2003.

2. Lee AW, Ng WT, Chan LL, Hung WM, Chan CC, Sze HC, Chan OS, Chang AT and Yeung RM: Evolution of treatment for nasopharyngeal cancer - success and setback in the intensitymodulated radiotherapy era. Radiother Oncol 110: 377-384, 2014.

3. Yu MC and Yuan JM: Epidemiology of nasopharyngeal carcinoma. Semin Cancer Biol 12: 421-429, 2002.

4. Fu ZT, Guo XL, Zhang SW, Zeng HM, Sun KX, Chen WQ and He J: Incidence and mortality of nasopharyngeal carcinoma in China, 2014. Zhonghua Zhong Liu Za Zhi 40: 566-571, 2018 (In Chinese).

5. Scott RS: Epstein-Barr virus: A master epigenetic manipulator. Curr Opin Virol 26: 74-80, 2017.

6. Zhou Y, Zeng Z, Zhang W, Xiong W, Li X, Zhang B, Yi W, Xiao L, Wu M, Shen S, et al: Identification of candidate molecular markers of nasopharyngeal carcinoma by microarray analysis of subtracted cDNA libraries constructed by suppression subtractive hybridization. Eur J Cancer Prev 17: 561-571, 2008.

7. Nakanishi Y, Wakisaka N, Kondo S, Endo K, Sugimoto H, Hatano M, Ueno T, Ishikawa K and Yoshizaki T: Progression of understanding for the role of Epstein-Barr virus and management of nasopharyngeal carcinoma. Cancer Metastasis Rev 36: 435-447, 2017.

8. Zeng Z, Zhou Y, Xiong W, Luo X, Zhang W, Li X, Fan S, Cao L, Tang K, Wu M, et al: Analysis of gene expression identifies candidate molecular markers in nasopharyngeal carcinoma using microdissection and cDNA microarray. J Cancer Res Clin Oncol 133: 71-81, 2007.

9. Zeng Z, Zhou Y, Zhang W, Li X, Xiong W, Liu H, Fan S, Qian J, Wang L, Li Z, et al: Family-based association analysis validates chromosome $3 \mathrm{p} 21$ as a putative nasopharyngeal carcinoma susceptibility locus. Genet Med 8: 156-160, 2006.

10. Xie SH, Yu IT, Tse LA, Mang OW and Yue L: Sex difference in the incidence of nasopharyngeal carcinoma in Hong Kong 1983-2008: Suggestion of a potential protective role of oestrogen. Eur J Cancer 49: 150-155, 2013.

11. Liu Q, Chen JO, Huang QH and Li YH: Trends in the survival of patients with nasopharyngeal carcinoma between 1976 and 2005 in Sihui, China: A population-based study. Chin J Cancer 32: 325-333, 2013.

12. Brouwer CL, Steenbakkers RJ, van den Heuvel E, Duppen JC, Navran A, Bijl HP, Chouvalova O, Burlage FR, Meertens H, Langendijk JA, et al: 3D Variation in delineation of head and neck organs at risk. Radiat Oncol 7: 32, 2012.

13. Tang LQ, Lu TY, Li Y, Guo SY, Zhong QY, Zou MS, Chen BL, Tang QN, Chen WH, Guo SS, et al: Patterns of Failure and Survival Trends Of 720 Patients with Stage I Nasopharyngeal Carcinoma Diagnosed from 1990-2012: A Large-scale Retrospective Cohort Study. J Cancer 9: 1308-1317, 2018.

14. Huang CI, Chen LF, Chang SL, Wu HC, Ting WC and Yang CC: Accuracy of a staging system for prognosis of 5-year survival of patients with nasopharyngeal carcinoma who underwent chemoradiotherapy. JAMA Otolaryngol Head Neck Surg 143: 1086-1091, 2017.

15. Shuang H, Feng J, Caineng C, Qifeng J, Tin J, Yuanyuan C and Xiaozhong C: The value of radical radiotherapy in the primary tumor of newly diagnosed oligo-metastatic nasopharyngeal carcinoma patients. Clin Transl Oncol: Jun 25, 2018 (Epub ahead of print). doi: 10.1007/s12094-018-1911-7.

16. Kwong DL, Sham JS, Au GK, Chua DT, Kwong PW, Cheng AC, Wu PM, Law MW, Kwok CC, Yau CC, et al: Concurrent and adjuvant chemotherapy for nasopharyngeal carcinoma: A factorial study. J Clin Oncol 22: 2643-2653, 2004.

17. Yan-Shan GE and Yan-Hong ZHOU: SDHA and tumor cell metabolism. Prog Biochem Biophys 45: 621-628, 2018.

18. Deshpande DA, Guedes AGP, Graeff R, Dogan S, Subramanian S, Walseth TF and Kannan MS: CD38/cADPR signaling pathway in airway disease: Regulatory mechanisms. Mediators Inflamm 2018: 8942042, 2018.

19. Itoh M, Ishihara K, Tomizawa H, Tanaka H, Kobune Y, Ishikawa J, Kaisho T and Hirano T: Molecular cloning of murine BST-1 having homology with CD38 and Aplysia ADP-ribosyl cyclase. Biochem Biophys Res Commun 203: 1309-1317, 1994.

20. Terhorst C, van Agthoven A, LeClair K, Snow P, Reinherz E and Schlossman S: Biochemical studies of the human thymocyte cell-surface antigens T6, T9 and T10. Cell 23: 771-780, 1981. 
21. Nakagawara K, Mori M, Takasawa S, Nata K, Takamura T, Berlova A, Tohgo A, Karasawa T, Yonekura H, Takeuchi T, et al: Assignment of CD38, the gene encoding human leukocyte antigen CD38 (ADP-ribosyl cyclase/cyclic ADP-ribose hydrolase), to chromosome 4p15. Cytogenet Cell Genet 69: 38-39, 1995.

22. Zhao YJ, Lam CM and Lee HC: The membrane-bound enzyme CD38 exists in two opposing orientations. Sci Signal 5: ra67, 2012.

23. Zhao YJ, Zhu WJ, Wang XW, Zhang LH and Lee HC: Determinants of the membrane orientation of a calcium signaling enzyme CD38. Biochim Biophys Acta 1853: 2095-2103, 2015.

24. Lin P, Owens R, Tricot G and Wilson CS: Flow cytometric immunophenotypic analysis of 306 cases of multiple myeloma. Am J Clin Pathol 121: 482-488, 2004

25. Sherbenou DW, Behrens CR, Su Y, Wolf JL, Martin TG III and Liu B: The development of potential antibody-based therapies for myeloma. Blood Rev 29: 81-91, 2015.

26. Bataille R, Jégo G, Robillard N, Barillé-Nion S, Harousseau JL, Moreau P, Amiot M and Pellat-Deceunynck C: The phenotype of normal, reactive and malignant plasma cells. Identification of 'many and multiple myelomas' and of new targets for myeloma therapy. Haematologica 91: 1234-1240, 2006.

27. Leo R, Boeker M, Peest D, Hein R, Bartl R, Gessner JE, Selbach J, Wacker $\mathrm{G}$ and Deicher H: Multiparameter analyses of normal and malignant human plasma cells: $\mathrm{CD} 38^{++}, \mathrm{CD} 56^{+}, \mathrm{CD}^{+} 4^{+}, \mathrm{cIg}^{+}$ is the common phenotype of myeloma cells. Ann Hematol 64 : 132-139, 1992

28. Hu Y, Wang H, Wang Q and Deng H: Overexpression of CD38 decreases cellular NAD levels and alters the expression of proteins involved in energy metabolism and antioxidant defense. J Proteome Res 13: 786-795, 2014

29. Liao S, Xiao S, Chen H, Zhang M, Chen Z, Long Y, Gao L, He J, $\mathrm{Ge} \mathrm{Y}, \mathrm{Yi} \mathrm{W}$, et al: The receptor for activated protein kinase $\mathrm{C}$ promotes cell growth, invasion and migration in cervical cancer. Int J Oncol 51: 1497-1507, 2017.

30. Hara A and Okayasu I: Cyclooxygenase- 2 and inducible nitric oxide synthase expression in human astrocytic gliomas: Correlation with angiogenesis and prognostic significance. Acta Neuropathol 108: 43-48, 2004.

31. Bose S, Yap LF, Fung M, Starzcynski J, Saleh A, Morgan S, Dawson C, Chukwuma MB, Maina E, Buettner M, et al: The ATM tumour suppressor gene is down-regulated in EBV-associated nasopharyngeal carcinoma. J Pathol 217: 345-352, 2009.

32. Ge Y, Zhang C, Xiao S, Liang L, Liao S, Xiang Y, Cao K, Chen H and Zhou Y: Identification of differentially expressed genes in cervical cancer by bioinformatics analysis. Oncol Lett 16 2549-2558, 2018

33. Zhang C, Peng L, Zhang Y, Liu Z, Li W, Chen S and Li G: The identification of key genes and pathways in hepatocellular carcinoma by bioinformatics analysis of high-throughput data. Med Oncol 34: 101, 2017.

34. Arndt C, Koristka S, Feldmann A, Bergmann R and Bachmann M: Coomassie Brilliant blue staining of polyacrylamide gels Methods Mol Biol 1853: 27-30, 2018.

35. Zheng D, Liao S, Zhu G, Luo G, Xiao S, He J, Pei Z, Li G and Zhou Y: CD38 is a putative functional marker for side population cells in human nasopharyngeal carcinoma cell lines. Mol Carcinog 55: 300-311, 2016.

36. Lefranc F, Le Rhun E, Kiss R and Weller M: Glioblastoma quo vadis: Will migration and invasiveness reemerge as therapeutic targets? Cancer Treat Rev 68: 145-154, 2018.

37. Liu CA, Chang CY, Hsueh KW, Su HL, Chiou TW, Lin SZ and Harn HJ: Migration/invasion of malignant gliomas and implications for therapeutic treatment. Int J Mol Sci 19: E1115, 2018.

38. Bhatia-Dey N, Kanherkar RR, Stair SE, Makarev EO and Csoka AB: Cellular senescence as the causal nexus of aging. Front Genet 7: 13, 2016.

39. Lee M and Lee JS: Exploiting tumor cell senescence in anticancer therapy. BMB Rep 47: 51-59, 2014.

40. Liao S, Xiao S, Chen H, Zhang M, Chen Z, Long Y, Gao L, Zhu G, He J, Peng S, et al: CD38 enhances the proliferation and inhibits the apoptosis of cervical cancer cells by affecting the mitochondria functions. Mol Carcinog 56: 2245-2257, 2017.

41. Abudoureyimu A and Muhemaitibake A: Arsenic trioxide regulates gastric cancer cell apoptosis by mediating cAMP. Eur Rev Med Pharmacol Sci 21: 612-617, 2017.

42. Das D, Khan PP and Maitra S: Endocrine and paracrine regulation of meiotic cell cycle progression in teleost oocytes: cAMP at the centre of complex intra-oocyte signalling events. Gen Comp Endocrinol 241: 33-40, 2017.
43. Goodman RP, Calvo SE and Mootha VK: Spatiotemporal compartmentalization of hepatic NADH and NADPH metabolism. J Biol Chem 293: 7508-7516, 2018

44. Tanabe H, Fujii Y, Okada-Iwabu M, Iwabu M, Nakamura Y, Hosaka T, Motoyama K, Ikeda M, Wakiyama M, Terada T, et al: Crystal structures of the human adiponectin receptors Nature 520: 312-316, 2015.

45. Karimi-Busheri F, Zadorozhny V, Li T, Lin H, Shawler DL and Fakhrai H: Pivotal role of CD38 biomarker in combination with CD24, EpCAM, and ALDH for identification of H460 derived lung cancer stem cells. J Stem Cells 6: 9-20, 2011.

46. Karimi-Busheri F, Rasouli-Nia A, Zadorozhny V and Fakhrai H: CD24 ${ }^{+} / \mathrm{CD} 38^{-}$as new prognostic marker for non-small cell lung cancer. Multidiscip Respir Med 8: 65, 2013.

47. Chouzouris TM, Dovolou E, Krania F, Pappas IS, Dafopoulos K, Messinis IE, Anifandis G and Amiridis GS: Effects of ghrelin on activation of Akt1 and ERK1/2 pathways during in vitro maturation of bovine oocytes. Zygote 25: 183-189, 2017.

48. Cheng R, Yong H, Xia Y, Xie Q, Gao G and Zhou X: Chemotherapy regimen based on sorafenib combined with 5-FU on HIF-1a and VEGF expression and survival in advanced gastric cancer patients. Oncol Lett 13: 2703-2707, 2017.

49. Ganesan R, Hos NJ, Gutierrez S, Fischer J, Stepek JM, Daglidu E, Krönke M and Robinson N: Salmonella Typhimurium disrupts Sirt1/AMPK checkpoint control of mTOR to impair autophagy. PLoS Pathog 13: e1006227, 2017.

50. Keyhani A, Huh YO, Jendiroba D, Pagliaro L, Cortez J, Pierce S, Pearlman M, Estey E, Kantarjian H and Freireich EJ: Increased CD38 expression is associated with favorable prognosis in adult acute leukemia. Leuk Res 24: 153-159, 2000

51. Aarhus R, Graeff RM, Dickey DM, Walseth TF and Lee HC: ADP-ribosyl cyclase and CD38 catalyze the synthesis of a calcium-mobilizing metabolite from NADP. J Biol Chem 270: 30327-30333, 1995.

52. Mallone R, Funaro A, Zubiaur M, Baj G, Ausiello CM, Tacchetti C, Sancho J, Grossi C and Malavasi F: Signaling through CD38 induces NK cell activation. Int Immunol 13: 397-409, 2001

53. Liao S, Xiao S, Zhu G, Zheng D, He J, Pei Z, Li G and Zhou Y: CD38 is highly expressed and affects the PI3K/Akt signaling pathway in cervical cancer. Oncol Rep 32: 2703-2709, 2014.

54. Blacher E, Ben Baruch B, Levy A, Geva N, Green KD, Garneau-Tsodikova S, Fridman M and Stein R: Inhibition of glioma progression by a newly discovered CD38 inhibitor. Int J Cancer 136: 1422-1433, 2015

55. Savarino A, Bottarel F, Calosso L, Feito MJ, Bensi T, Bragardo M, Rojo JM, Pugliese A, Abbate I, Capobianchi MR, et al: Effects of the human CD38 glycoprotein on the early stages of the HIV-1 replication cycle. FASEB J 13: 2265-2276, 1999.

56. Yamada M, Mizuguchi M, Otsuka N, Ikeda K and Takahashi H: Ultrastructural localization of CD38 immunoreactivity in rat brain. Brain Res 756: 52-60, 1997.

57. Churchill GC, O'Neill JS, Masgrau R, Patel S, Thomas JM, Genazzani AA and Galione A: Sperm deliver a new second messenger: NAADP. Curr Biol 13: 125-128, 2003.

58. Dianzani U, Funaro A, DiFranco D, Garbarino G, Bragardo M, Redoglia V, Buonfiglio D, De Monte LB, Pileri A and Malavasi F: Interaction between endothelium and $\mathrm{CD}^{+} \mathrm{CD} 45 \mathrm{RA}^{+}$ lymphocytes. Role of the human CD38 molecule. J Immunol 153: 952-959, 1994.

59. Guse AH, da Silva CP, Berg I, Skapenko AL, Weber K, Heyer P, Hohenegger M, Ashamu GA, Schulze-Koops H, Potter BV, et al: Regulation of calcium signalling in T lymphocytes by the second messenger cyclic ADP-ribose. Nature 398: 70-73, 1999.

60. Kim SY, Cho BH and Kim UH: CD38-mediated $\mathrm{Ca}^{2+}$ signaling contributes to angiotensin II-induced activation of hepatic stellate cells: Attenuation of hepatic fibrosis by CD38 ablation. J Biol Chem 285: 576-582, 2010.

61. Guedes AG, Rude EP and Kannan MS: Potential role of the CD38/cADPR signaling pathway as an underlying mechanism of the effects of medetomidine on insulin and glucose homeostasis. Vet Anaesth Analg 40: 512-516, 2013.

62. Young LS and Rickinson AB: Epstein-Barr virus: 40 years on. Nat Rev Cancer 4: 757-768, 2004.

63. Schiattarella GG and Hill JA: Therapeutic targeting of autophagy in cardiovascular disease. J Mol Cell Cardiol 95: 86-93, 2016.

64. Yang E, Al-Mugheiry TS, Normando EM and Cordeiro MF: Real-time imaging of retinal cell apoptosis by confocal scanning laser ophthalmoscopy and its role in glaucoma. Front Neurol 9: 338,2018 . 
65. Kountouras J, Kouklakis G, Zavos C, Chatzopoulos D, Moschos J, Molyvas E and Zavos N: Apoptosis, inflammatory bowel disease and carcinogenesis: Overview of international and Greek experiences. Can J Gastroenterol 17: 249-258, 2003.

66. Blacher E, Dadali T, Bespalko A, Haupenthal VJ, Grimm MO, Hartmann T, Lund FE, Stein R and Levy A: Alzheimer's disease pathology is attenuated in a CD38-deficient mouse model. Ann Neurol 78: 88-103, 2015.

67. Levy A, Blacher E, Vaknine H, Lund FE, Stein R and Mayo L: CD38 deficiency in the tumor microenvironment attenuates glioma progression and modulates features of tumor-associated microglia/macrophages. Neuro Oncol 14: 1037-1049, 2012.

68. Karakasheva TA, Waldron TJ, Eruslanov E, Kim SB, Lee JS, O'Brien S, Hicks PD, Basu D, Singhal S, Malavasi F, et al CD38-expressing myeloid-derived suppressor cells promote tumor growth in a murine model of esophageal cancer. Cancer Res 75: 4074-4085, 2015.

69. Poret N, Fu Q, Guihard S, Cheok M, Miller K, Zeng G, Quesnel B, Troussard X, Galiègue-Zouitina S and Shelley CS: CD38 in hairy cell leukemia is a marker of poor prognosis and a new target for therapy. Cancer Res 75: 3902-3911, 2015.

70. Deaglio S, Capobianco A, Bergui L, Dürig J, Morabito F, Dührsen U and Malavasi F: CD38 is a signaling molecule in B-cell chronic lymphocytic leukemia cells. Blood 102: 2146-2155, 2003.

71. Chini CC, Guerrico AM, Nin V, Camacho-Pereira J, Escande C, Barbosa MT and Chini EN: Targeting of NAD metabolism in pancreatic cancer cells: Potential novel therapy for pancreatic tumors. Clin Cancer Res 20: 120-130, 2014.

72. Sherr CJ: G1 phase progression: Cycling on cue. Cell 79: 551-555, 1994.

73. Bartek J, Bartkova J and Lukas J: The retinoblastoma protein pathway and the restriction point. Curr Opin Cell Biol 8: 805-814, 1996.

74. Donjerkovic D and Scott DW: Regulation of the G1 phase of the mammalian cell cycle. Cell Res 10: 1-16, 2000.

75. Zhou P, Jiang W, Weghorst CM and Weinstein IB: Overexpression of cyclin D1 enhances gene amplification. Cancer Res 56: 36-39, 1996.

76. Izzo JG, Papadimitrakopoulou VA, Li XQ, Ibarguen H, Lee JS, Ro JY, El-Naggar A, Hong WK and Hittelman WN: Dysregulated cyclin D1 expression early in head and neck tumorigenesis: In vivo evidence for an association with subsequent gene amplification. Oncogene 17: 2313-2322, 1998.
77. Sapio L, Gallo M, Illiano M, Chiosi E, Naviglio D, Spina A and Naviglio S: The Natural cAMP elevating compound forskolin in cancer therapy: Is It Time? J Cell Physiol 232: 922-927, 2017.

78. Banerjee J, Papu John AM, Al-Wadei MH and Schuller HM Prevention of pancreatic cancer in a hamster model by cAMP decrease. Oncotarget 7: 44430-44441, 2016.

79. Xie L, Boyle D, Sanford D, Scherer PE, Pessin JE and Mora S: Intracellular trafficking and secretion of adiponectin is dependent on GGA-coated vesicles. J Biol Chem 281: 7253-7259, 2006.

80. Miele M, Costantini S and Colonna G: Structural and functional similarities between osmotin from Nicotiana tabacum seeds and human adiponectin. PLoS One 6: e16690, 2011.

81. Liu DG, Liu HL, Song TJ, Huang HY, Li X and Tang QQ: Functional expression of the globular domain of human adiponectin in Pichia pastoris. Biochem Biophys Res Commun 363: 769-775, 2007.

82. Feng L, Tao L, Dawei H, Xuliang L and Xiaodong L: HIF-1a expression correlates with cellular apoptosis, angiogenesis and clinical prognosis in rectal carcinoma. Pathol Oncol Res 20: 603-610, 2014.

83. Robb KP, Cotechini T, Allaire C, Sperou A and Graham CH: Inflammation-induced fetal growth restriction in rats is associated with increased placental HIF-1 $\alpha$ accumulation. PLoS One 12: e0175805, 2017.

84. Guo Y, Han B, Luo K, Ren Z, Cai L and Sun L: NOX2-ROSHIF-1 $\alpha$ signaling is critical for the inhibitory effect of oleanolic acid on rectal cancer cell proliferation. Biomed Pharmacother 85: 733-739, 2017.

85. Madu C, Li L and Lu Y: Selection, analysis and improvement of anti-angiogenesis compounds identified by an anti-HIF-1 $\alpha$ screening and validation system. J Cancer 7: 1926-1938, 2016.

86. Kim MH, Jeong YJ, Cho HJ, Hoe HS, Park KK, Park YY, Choi YH, Kim CH, Chang HW, Park YJ, et al: Delphinidin inhibits angiogenesis through the suppression of HIF-1 $\alpha$ and VEGF expression in A549 lung cancer cells. Oncol Rep 37: 777-784, 2017.

This work is licensed under a Creative Commons Attribution-NonCommercial-NoDerivatives 4.0 International (CC BY-NC-ND 4.0) License. 